\title{
Ageing AND PRODUCTIVITY GROWTH: ARE THERE MACRO-LEVEL COHORT EFFECTS OF HUMAN CAPITAL?
}

\author{
MARTIN WERDING
}

CESIFO WORKING PAPER NO. 2207

CATEGORY 5: FisCAl POLICY, MACROECONOMICS AND GROWTH JANUARY 2008

\footnotetext{
An electronic version of the paper may be downloaded

- from the SSRN website:

- from the RePEc website:

- from the CESifo website:

www.SSRN.com

www.RePEc.org

www.CESifo-group.org/wp
} 


\title{
Ageing AND PRODUCTIVITY GROWTH: ARE THERE MACRO-LEVEL COHORT EFFECTS OF HUMAN CAPITAL?
}

\begin{abstract}
Slower growth of the labour force and an increase in old-age dependency will reduce the growth of aggregate output and output per capita in many developed countries. However, a major question is whether there is any systematic link between demographics and the productivity of those who will still be active during the up-coming period of demographic ageing. As productivity is difficult to investigate at a micro level, the paper builds on a large macro-data panel covering developed as well as developing countries and explores the impact of the age composition of the labour force on levels and growth rates of output per worker as well as on total factor productivity (TFP). The results confirm earlier findings by Feyrer (2007), pointing to an inversely $U$-shaped relationship between the share of workers in different age groups and productivity which mainly works through the TFP channel and is effectively much stronger than what can be observed at a micro level. In-depths analyses suggest that cohort effects in human-capital accumulation may contribute to this pattern, but do not explain it. The paper concludes with simulations for a number of OECD countries showing that the impact of projected ageing of the labour force on productivity and per-capita growth could be really substantial in some cases.
\end{abstract}

JEL Code: E13, J11, O47, O50.

Keywords: demographic change, economic growth, total factor productivity, macro-level panel regressions, simulations.

\author{
Martin Werding \\ Ifo Institute for Economic Research \\ at the University of Munich \\ Poschingerstrasse 5 \\ 81679 Munich \\ Germany \\ werding@ifo.de
}

January 2008

Research for his paper has been done while I was staying as a visiting professor at the Institute of Economic Research at Hitotsubashi University, Tokyo. I am deeply indebted to my colleagues there, most of all to Noriyuki Takayama, for an atmosphere of kind hospitality and many stimulating discussions. For helpful suggestions and comments I also thank Kyoji Fukao and participants of the IER Research seminar. 


\section{Ageing and Productivity Growth: Are There Macro-level Cohort Effects of Human Capital?}

\section{Introduction}

Over the $20^{\text {th }}$ century, there has been a secular decline in fertility rates in virtually all industrialized countries, with the number of births mostly falling below a "replacement level” during the last three decades. A parallel, strong increase in longevity adds to the picture of demographic ageing as a current mega-trend. However, continuing reductions in age-specific mortality rates now mainly relate to years of age in which individuals are clearly beyond their active life span. As a result, most developed countries will be faced with a considerable slow-down in growth, in many cases even a decline, in their labour force. With an increasing share of older individuals, changes in total population growth tend to move in the same direction, but will be far less pronounced.

The economic implications of these changes are of first-order significance. Nevertheless, disputes about many of the potential consequences are still unsettled. For example, surprisingly little is actually known regarding the impact of large shifts in the age composition of the labour force on productivity growth. Meanwhile, it is easy to see that the productivity of those who will still be active during the up-coming period of overt demographic ageing is really one of the key issues arising in this context. Conventional economic wisdom points to a number of diverging effects, but does not offer any unambiguous conclusions regarding their net impact. In a recent paper, Feyrer (2007) has come up with empirical results regarding a link between labour-force demographics and total factor productivity (TFP) that appear to be so strong and robust that they are hard to believe but ought to be taken seriously. In this paper, I will reconstruct Feyrer's analysis from scratch and try to extend it in several ways. First, in the empirical work I will add ten more years of data which are taken from a period, 1991 to 2000, when economic growth was more business as usual in many countries than in the early post-war period until well into the 1960s. Second, I will look at the role of cohort effects in human-capital accumulation for the impact of demographics on TFP and TFP growth.

The paper is organized as follows. In Section 2, I will browse through the body of existing literature, discussing the main observations that have been made regarding the relationship between population growth and fertility on the one hand and economic performance on the other. In Section 3, I restate Feyrer's simple macroeconomic model of how the age composition of the labour force might affect productivity. Section 4 reports on procedures and results of an empirical assessment of the model, based on a large macro-data panel spanning a long time series and covering developed as well as devel- 
oping countries. Section 5 concludes with some illustrative simulations, also commenting on promising paths for future research in this area.

\section{Productivity and demographic ageing: ideas and observations}

\subsection{Participation, dependency, and "capital deepening" in standard growth theory}

Neglecting the age composition of the labour force and concentrating on its size, a conventional neoclassical growth model predicts a negative "participation effect" on aggregate output, a negative "dependency effect" on output per capita, and an increase in output per worker - i.e., in labour productivity - through "capital deepening” if the growth rate of the labour force diminishes and the dependency ratio increases. The first of these effects is of little importance, and the second is relevant, but largely inevitable. The impact of demographic change on productivity should actually be the key concern but, at closer inspection, capital deepening alone turns out to be a rather weak counter-effect.

To see all this, assume for an instant that the growth rate of output per worker -i.e., productivity growth - were exogenously given, hence entirely unaffected by demographic ageing. If the number of individuals who engage in production grows at a lower rate than in the past, the growth rate of aggregate output will slow down correspondingly. Of course, one need not really worry about this reduction in economic growth along its "extensive" margin; one may simply have to get used to smaller growth figures. What is more important is that "intensive" growth of per-capita output, which is sometimes used as a rough indicator of individual well-being, is also likely to decline. The reason is that, whatever the precise trends, the growth rate of total population will usually not decelerate as much as that of the working-age population, and the share of the population that is economically inactive will go up substantially. Both these effects that are straightforward from the simple arithmetic of growth figure prominently in a number of recent simulation exercises regarding the economic consequences of demographic ageing. ${ }^{1}$ Yet, in themselves, they contain little economics.

Things are different with respect to capital deepening, or (inverse) “capital dilution” as it was traditionally termed when the labour force was growing almost everywhere. In the standard neoclassical growth model suggested by Solow (1956) and Swan (1956), output per worker is co-determined by the capital-labour ratio, and the saving rate is taken to be exogenous. If, in such an environment, the labour force starts growing more

\footnotetext{
See, for example, Martins et al. (2005) or European Commission (2005). There, the focus is on ways to increase labour-force participation to counter the wide-spread downward trend in the working-age population. In case this can be accomplished, there will be a positive effect for aggregate and percapita growth, but the results are still mainly governed by the simple rule of proportion applied above.
} 
slowly than it did before, the immediate response in the capital stock is limited to a less than proportional decline in its growth rate which becomes stronger and stronger until the rate of capital accumulation has aligned to the growth rate of the labour force. During this entire transition period and also in the final steady state, there is thus more capital per worker than with a higher rate of labour-force growth, and labour productivity increases. In terms of aggregate output, however, the negative participation effect of slower growth of the labour force always dominates the (second-order) effect of capital deepening. In terms of output per capita, one would have to make highly unrealistic assumptions regarding the parallel change in total population growth for the overall effect to be neutral, let alone positive. Last but not least, capital deepening as such could be weakened, but also reinforced, if the saving rate were not exogenous as it is in the neoclassical standard model, but determined endogenously by individuals who optimize their life-time consumption profile. ${ }^{2}$

\subsection{The empirical evidence thus far}

Most of the empirical work on economic growth done prior to the 1990s is now clearly out-dated, due to improvements in both econometric methodology and data availability that have been achieved since then. Brandner and Dowrick (1994) are thus the first to investigate the impact of demographics on economic performance, specifically on percapita output and per-capita growth, in an up-to-date fashion for a large panel of developed and developing countries. Building on the Solow-Swan model and using population growth as the relevant regressor, they find that, to the extent that they can isolate it, the capital-deepening effect is weak and insignificant. Effectively lumping together the participation and dependency effects, they find a much stronger impact of the workingage share of population which is both positive and significant. The role of investment for output and growth is also positive and significant, as one should expect. Yet, the most important source of variation in output and growth appears to be a productivity indicator taken to reflect the current stage of technological progress in each country.

In a more recent paper, Ahituv (2001) uses an augmented model which includes variables reflecting average qualifications of workers, i.e., human capital accumulation. He concentrates on capital deepening and dependency effects as the two main channels for how demographics could affect output per capita in an even larger panel of countries. Using fertility rates instead of total population growth as a regressor, he finds the

2 In a model with endogenous saving, the impact of a declining labour force on the aggregate saving rate is truly ambiguous. Heuristically, there are two opposing effects: individuals may save less as an increasing capital-labour ratio puts the rate of return under pressure; they may as well save more to keep up consumption at old age. Ultimately, this is a matter of the intertemporal elasticity of substitution between consumption at different ages (Werding 2007, Appendix A.1), hence an empirical question. 
former effect to be significant. Still, his estimates suggest that the latter channel is more important in explaining a negative effect of high fertility on output per capita. Like Brandner and Dowrick (1994), Ahituv (2001) looks at contemporaneous relationships only - i.e., effects of current fertility rates on current economic performance ${ }^{3}$ - thus neglecting long-term consequences of changes in fertility for economic growth that are currently moving to the fore and should therefore rank high on the research agenda.

An important step in this direction is taken by Lindh and Malmberg (1999) who are the first to investigate the idea that, in developed countries, there may be an impact of the age composition of the population, which is mainly shaped by past birth rates, on the growth rate of output per worker. Their results indicate that, controlling for net investment and labour-force growth within an overall model of transitional growth with gradual adjustments of technology, there is a significant positive effect of the share of those who are currently aged 50-64 years. The share of elderly people (aged 65 and over) has a significant negative effect on productivity growth, while younger age groups have ambiguous and largely insignificant effects. Perhaps, one of the main shortcomings of their study is that the demographic variables used by Lindh and Malmberg (1999) relate to total population, not to the working-age population or the labour force, and therefore do not allow for stronger conclusions regarding the precise mechanisms at work.

Another study dealing with effects of the age composition on productivity and productivity growth that uses data relating to both population and labour force is provided by Feyrer (2007). Building on a human-capital augmented growth model and a conventional growth-accounting approach (Solow 1957), his main interest lies with the impact of demographics on the state and dynamics of technological progress, or "total factor productivity", which has often been found to be very important for explaining actual growth processes, respectively, their variation across countries and over time. ${ }^{4}$ His analyses relate to up to 87 developed as well as to developing countries, and his data set spans the period from 1960 to 1990 . His major finding is an inversely $U$-shaped relationship between changes in the age structure of the labour force and the growth rate of TFP which peaks for workers aged 40-49. Furthermore, this pattern is very pronounced, much stronger in fact than anything that can be observed at the micro level, and it appears to be robust against numerous modifications that are meant to detect any biases.

There is also a number of other recent papers, such as Bloom et al. (2007), which demonstrate a growing interest in the link between demographics and economic growth in general. Yet, the positive relationship that they find between growth of per-capita

3 Therefore, Ahituv (2001) also tests for reverse causality, concluding that the negative relation between fertility and output per capita is effectively the result of bi-directional dependence.

4 For an extensive survey of empirical work that backs this conclusion, see Easterly and Levine (2000). 
output and changes in the overall activity rate (i.e., 1 - total dependency ratio) should not be surprising, simply due to the definition of both these variables.

\subsection{Age-related productivity differentials}

Another strand of the literature stresses that a given worker's productivity could systematically differ over his or her active period of life for reasons such as differences in experience, depreciation of knowledge or age-related trends in physical and mental capabilities. Based on the link between productivity and wages, this is often illustrated using micro-level estimates of Mincerian wage equations (Mincer 1974) which measure life-cycle profiles of individual wage rates, usually differentiated by gender, as a function of educational attainments, job experience or age (allowing for non-linear effects) and a number of socio-economic background characteristics. Typically, these profiles exhibit a strong increase until workers are in their 40s and a moderate decline toward the end of the working life. Consequently, if the number of older workers increases vis$\grave{a}$-vis that of prime-aged workers, there could be a reduction in average productivity.

There are several objections to interpreting Mincer-type wage profiles as indicating age-related differences in productivity. First, in estimates based on cross-section data, seemingly age-related trends may effectively be due to cohort effects arising from changes in educational behaviour over time. Levels of qualification are explicitly controlled for in the estimation, yet this may not fully remove the distortion. Second, lifecycle profiles of wages may effectively reflect seniority rules of pay which have little, if anything, to do with age-related patterns of productivity. Furthermore, using data that appear to be suited to avoid these two problems, Börsch-Supan (2003) demonstrates that, to the extent that they show up in individual wage earnings, age-specific productivity differentials are unlikely to have more than negligible effects for the time path of average productivity. ${ }^{5}$ Even under extreme assumptions regarding the size of these differentials, he finds that changes in the age distribution of the labour force projected for Germany until 2050 - where these changes are rather strong - may reduce productivity growth only by up to 0.15 percentage points per year.

An important caveat with respect to all kinds of micro-level approaches in this area is that productivity (and its life-cycle profile) is not, at least not fully, an individual

\footnotetext{
Börsch-Supan (2003) looks at the structure of two different earnings profiles relating to the employees of a major service company in the US (taken from Kotlikoff and Wise 1989), a genuinely longitudinal profile for salesmen whose pay is mainly performance-related and an artificial profile for salarymen who are newly hired at different ages. The restriction to new hires is meant to neutralize the effects of seniority remuneration which may be highly relevant for salaried workers. It turns out that both profiles exhibit more variation than simple cross-section results and that the profile for salaried workers shows an even stronger decline of earnings at higher ages than that for salesmen. This may be partly due to a selection effect between those who stay in a job and those who have to find a new employer.
} 
characteristic. Rather, it is the outcome of a complex interaction with other workers and other factors of production which takes place within a certain economic environment constituted by the available technology, public infrastructure, characteristics of a given firm and sector, and many other things beside. This definitely needs to be taken into account when assessing the impact of changes in the size and the composition of the labour force on aggregate economic performance. Therefore, Mincerian wage profiles may not convey all that matters here, and one may indeed have to employ the rough tools of macroeconomic theory to address the impact of demographic change on economic performance and, specifically, productivity growth.

\section{A macroeconomic model}

The basic idea which is further investigated in this paper is the one already pursued by Lindh and Malmberg (1999) as well as Feyrer (2007), viz. that labour productivity and its growth could be influenced by the age structure of the labour force. From the literature on age-related productivity differentials (see Section 2.3), one can already infer that such effects may not so much affect productivity that is directly attributable to individual workers and can be rewarded in terms of wages. Instead, they may mainly work via total factor productivity, i.e., technological progress and technology dissemination.

To formalize this idea closely following Feyrer (2007), let us start from a CobbDouglas variant of a neoclassical production function, augmenting it with a variable $h$ representing human capital per worker, or the "quality of labour", and assuming technological progress, measured by a parameter $A$, to be "labour-augmenting". As the model will be tested using annual data for a large number of countries, we may also add a country index $i$ and a time index $t$.

$$
Y_{i t}=K_{i t}^{\alpha}\left(A_{i t} h_{i t} L_{i t}\right)^{1-\alpha}
$$

To be sure, none of these are novel features. Equation (1) is essentially taken from Hall and Jones (1999). Taking into account human capital is important as there is a lot of variation across countries and over time in this variable, a major drawback for many older studies being that this has not been measurable in a reliable fashion. The assumption that technological progress is labour-augmenting, or "Harrod-neutral”, is necessary for the model to have a steady state (Uzawa 1961). The assumption that the production function is Cobb-Douglas reconciles this definition with the alternative one of technological progress being "Hicks-neutral" which is needed for growth accounting to be applicable. ${ }^{6}$

6 Technological progress is said to be labour-augmenting, or Harrod-neutral (with reference to Harrod 1942), if it does not affect the output shares of capital and labour for a given capital-output ratio. It is 
Re-writing (1) in terms of output per worker, $q=Y / L$, and re-arranging yields

$$
q_{i t}=k_{i t}^{\alpha}\left(A_{i t} h_{i t}\right)^{1-\alpha}=\kappa_{i t}^{\alpha /(1-\alpha)} A_{i t} h_{i t},
$$

with the capital coefficient $\kappa=K / Y=k / q$. Taking natural logarithms leads to a linear decomposition by which $A$ can be isolated. The result is

$$
\ln A_{i t}=\ln q_{i t}-\frac{\alpha}{1-\alpha} \ln \kappa_{i t}-\ln h_{i t} .
$$

Calculating first differences, one obtains (exponential) growth rates of $A$ and the other variables, based on $\ln \left(x_{t} / x_{t-1}\right)=\ln x_{t}-\ln x_{t-1} \equiv \Delta \ln x_{t}$ (and $\ln 1=0$ ), whereby

$$
\Delta \ln A_{i t}=\Delta \ln q_{i t}-\frac{\alpha}{1-\alpha} \Delta \ln \kappa_{i t}-\Delta \ln h_{i t} .
$$

Equations (3) and (4) can be seen as prescriptions of how to calculate TFP both in levels and growth rates based on data regarding $Y, K, L$ and $h$, thereby controlling for the role of pure factor accumulation for output and productivity growth. Bearing in mind that $A$ is often found to be the most important driver of economic growth, one can then go ahead and subject the measures obtained for $\ln A$ and $\Delta \ln A$ to further examination.

Again following Feyrer (2007), I then assume that $q$ is influenced - mainly through the TFP parameter $A$ - by the age composition of the labour force, implying that the latter may have an impact on TFP levels, while changes in the age composition of the active population may then affect TFP growth. The age composition of the labour force is therefore represented by an index, $\Lambda$, with

$$
\Lambda_{i t}=\mathrm{e}^{\sum_{\mathrm{s}} \beta_{s} L_{s i t}},
$$

where $L_{s}$ is the share of age group $s$ in the total labour force. Inserting (5) in (3) and (4) via the assumption that $A=\gamma \Lambda$ yields a decomposition of the TFP residual,

$$
\ln A_{i t}=\ln \gamma_{i t}+\ln \Lambda_{i t}=\ln \gamma_{i t}+\sum_{s} \beta_{s} L_{s i t},
$$

or, in terms of first differences,

called "Hicks-neutral" (after Hicks 1932) if, as in $Y=T K^{\alpha} L^{1-\alpha}$, it does not affect the ratio of marginal productivities of capital and labour for a given capital-labour ratio.

Note that the definitions of Hicks-neutrality and Harrod-neutrality are not mutually exclusive. However, they can only be met simultaneously with a production function that exhibits a constant unit elasticity of substitution. Furthermore, a constant-returns-to-scale Cobb-Douglas function (where the sum of all partial output elasticities is unity and the output shares of all factors of production are simply constant) is the only functional form fulfilling this condition. To see the equivalence, simply assume that the TFP measure $A$ included in (1) is related to $T$ by the monotonic transformation $A=T^{1 /(1-\alpha)}$. 


$$
\Delta \ln A_{i t}=\Delta \ln \gamma_{i t}+\sum_{s} \beta_{s} \Delta L_{s i t}
$$

which easily lend themselves as testable hypotheses. To obtain regression equations, one simply has to split $\ln \gamma_{i t}$ into a constant $\gamma$ (that disappears when differencing), a time-invariant country fixed effect $\lambda_{i}$, and a pure time trend $\mu_{t}$, and add an error term $\varepsilon_{i t}$.

Note that the assumption of the TFP residual $A$ being a function of (the structure of) $L$, makes the theoretical model come close to a model of endogenous growth in the tradition of Lucas (1988) and Uzawa (1965), with human capital as an engine of TFP growth. This observation raises two issues. First, an endogenous-growth setting which implies that there are super-linearities linked to one of the production factors entering the $F(\cdot)$-functional would be at odds with the application of the basic growth-accounting framework which is necessary to measure $A$ in the first place. A way out of this dilemma is to interpret the model as a model of transitional growth (following Barro and Sala-i-Martin 1995), such that the TFPs measured for each country would not reflect genuine technological progress ("inventions"), but the current state of technology adoption (“innovation”). In a process of universal convergence, all countries were then moving towards the uniform production possibilities frontier from different starting points and at different speeds, while the frontier itself would not depend on the age composition of the labour force. Alternatively, one could simply accept the internal inconsistency of the theoretical model, as there is no other way to isolate $A$, and take it to yield an imperfect test on whether there is genuine endogenous growth linked to the structure of $L-$ a conclusion which would not be supported empirically, as we will see. Second, having gone this far, one may wonder whether the human capital of workers should not also play a role for levels and changes in $A$. I will further look into this feature in Section 4.2, after estimating the model in its current form and discussing the results.

From a technical point of view, the model suggested here for empirical testing has a number of nice features. The age-structure variables which are considered the main determinants of TFP and TFP growth are not likely to be endogenously linked by the dependent variables, as they are essentially determined by decisions taken some 20 to 60 years ago. ${ }^{7}$ This avoids problems regarding the direction of causality that are notorious with respect to many other potential determinants of output or output growth, such as trade, investment, education, political institutions, etc. Also, unlike other variables that are plausibly exogenous, such as geographical characteristics, demographic variables not only exhibit variation across countries but also considerable time-series variation, at least in the industrialized world. Serial correlation, another potential problem that typi-

7 This is certainly true with respect to past fertility rates and their impact on today's age structure of the labour force, probably less so with respect to migration. I will return to these qualifications later on. 
cally plagues time-series analyses of the determinants of output, is naturally being dealt with in this set-up when switching to first differences, not as a technical response but as a variant of the model which has a material interpretation. Provided it exists in the levelestimates based on equation (6), the problem of serial correlation is also mitigated by the fact that I effectively use data collected at 5-year intervals.

Building on Feyrer (2007), I will mainly look at the role of the age composition of the labour force for TFP and TFP growth. However, the work by Brandner and Dowrick (1994) or Ahituv (2001) suggests that changes in demographic variables may also affect saving and investment, hence the entire time path of the physical capital stock (see Section 2.2). Similar things may apply to the stock of human capital. Estimates regarding the role of demographic change for economic growth could therefore be biased if these alternative channels were not taken into account. To check whether this potential bias exists, and also to determine the relative importance of the impact on TFP, running additional regressions regarding the impact on the broader productivity measure $q$ and $\Delta q$ and on any of the components of equations (3) and (4) may thus be useful.

\section{Data and estimates}

\subsection{Demographics, TFP and TFP growth}

The data base which has been set up for this study spans a time frame from 1960 to 2000, at 5-year intervals, and covers up to 106 countries, among them 27 OECD countries which are taken to represent the developed world. ${ }^{8}$ As both growth experience and current demographic trends in most developed countries differ from those in the rest of the world, I look at the larger "all-countries" panel including as many observations as possible to avoid a selection bias, but I will run separate regressions for the OECD countries to see whether they show any peculiarities.

The estimates rely to a great deal on measures and procedures that have been developed in recent empirical growth research. Throughout, I up-date data used in earlier work and re-construct all transformations from scratch. Specifically, the productivity measure $q_{i t}$ that serves as a starting point for calculating the TFP residual is output per worker as constructed in the Penn World Tables (“PWT 6.2”, Heston et al. 2006). Capital per worker $k_{i t}$ is calculated applying a "perpetual-inventory" method to PWT 6.2 data following Easterly and Levine (2000), ${ }^{9}$ and $\kappa_{i t}$ is simply defined as $k_{i t} / q_{i t}$. Human

For a list of the countries covered, see Appendix A.1.

$9 \quad$ The value of the initial capital stock per worker is estimated to be $i /(g+\delta) q_{0}$; the investment share $i$ is calculated as a 10-year average from 1960 onward (later if data become available only later); "steadystate" growth $g$ is calculated as a weighted 10-year average of the economy's aggregate growth rate and the world growth rate of aggregate output; the depreciation rate $\delta$ is assumed to be $7 \%$; and initial output per worker $q_{0}$ is a 3-year average (for further details, see Easterly and Levine 2000, footnote 3). 
capital per worker is measured as $h_{i t}=e^{\phi\left(s_{i t}\right)}$, following Hall and Jones (1999) and using data on educational attainments provided by Barro and Lee (2001) and on returns to schooling provided by Psacharopoulos (1994). ${ }^{10}$ Based on evidence from a host of international studies, capital's share of output, $\alpha$, is simply assumed to be $1 / 3$ (see, e.g., Gollin 2002). The age composition of the labour force is measured by the relative size of 10-year age groups (L10-19, L20-29, etc., representing the share of those aged 1019, 20-29, etc. in the active population). Data are taken from the ILO's (2007) LABORSTA database, where they are available at 10 -year intervals. To run estimates based on 5-year intervals, missing values are imputed using data on the age structure of total population that are provided by the UN Population Division (2006).

The results of a first series of estimates that are based on equation (6), essentially replicating Feyrer's (2007) analysis, are summarized in Table $1 .{ }^{11}$ Here, the dependent variable is the TFP residual in levels; TFP growth will be looked at in the next step. Specifications that differ from Model 1 ("M 1") to Model 6 ("M 6") are meant to explore, first, how much additional structure is needed for a simple regression of the TFP term on the $L$-variables to yield meaningful results and, second, how robust these results are with respect to alternative estimation procedures. M 1 is a simple OLS regression, with all the available data simply pooled together, while M 2 adds country dummies and M 3, in addition, time dummies. ${ }^{12}$ Allowing for country-specific effects contributes substantially to shaping results regarding the age-structure variables $L 10-19$ through $L 60+$. ( $L 40-49$ is omitted from the regression and serves as a reference group, the coefficients for the other $L$-variables measuring effects relative to those of this prime-aged group of workers.) Introducing time dummies further modifies the pattern of the $L$-coefficients, but does not change their structure altogether.

To understand the progress from M 1 to M 3 more fully, it is important to keep in mind what the inclusion of time and country-specific effects implies in the present framework. Note, first of all, that all cross-country differences in output and productivity that are due to differences in investment in physical and human capital should already have been taken into account when calculating the TFP residual. The estimates therefore focus on differences in productivity, both over time and across countries, that are not explained by factor accumulation alone. Including time dummies in the estimation then allows for TFP levels to vary over time with trend growth rates that are com-

10 Here, $s_{i t}$ are average years of schooling in the active population; the function $\phi(s)$ is piecewise linear over years of schooling at different levels; it exhibits decreasing returns to higher education and is thus similar to the education-related components of a Mincerian wage regression (see Section 2.1).

11 See Appendix A.2 for descriptive statistics related to the variables used in the analysis.

12 To control for cross-country heterogeneity in a rough fashion, M 1 includes dummies for OECD countries and a subset of "least” developed countries as additional regressors. 
mon to all the countries considered. Including country-level dummies means that individual countries may be away, some more and some less, from the current technology frontier defined at a global level. Against this background, additional effects of the $L$ variables indicate that the age structure of the labour force may matter for closing, or widening, the gap to the world productivity frontier, for instance, by playing a role for the adoption and use of new technologies.

Model M 4 is very similar to M 3. Now, however, residuals are clustered by countries as a means to avoid potential distortions of the standard errors through serial correlation. Estimated coefficients are unchanged against M 3, showing a pronounced agerelated pattern of the impact of the $L$-variables on the log-TFP measure. What is more interesting for the moment is that the significance of these effects is next to unaffected. Four of the five age-structure variables are significant in the regression relating to all countries in the sample. The same is true for an otherwise identical regression based on OECD countries only. Additional tests reveal that, in models $\mathrm{M} 4 \mathrm{a}$ and $\mathrm{M} 4 \mathrm{~b}$, all coefficients of the five $L$-variables are jointly significant at a 1-percent level for all countries, at a 5 -percent level in the case of OECD countries. ${ }^{13}$

The search for an appropriate specification is continued in M 5 and M 6, a genuine fixed-effects model and a random-effects model. Apart from the constant, the coefficients of M 5 are identical to those of M 3 and M 4, and their significance turns out to be as high as in $\mathrm{M}$ 3, that is, without the adjustment in standard errors through clustered residuals. At the same time, the assumption of country-level fixed effects ${ }^{14}$ takes away some of the explanatory power of the other regressors. In the regression covering all countries, this can be seen from the moderate results regarding " $R^{2}$ within" (measuring the model's fit over time for a given country) and the new, combined measure of the "overall $R^{2}$ " (over time and across countries); in the OECD regression, the "within" fit is still rather high. All these observations are not uncommon in a context like the present one. M 6 uses the generalized least squares (GLS) method for analysing an otherwise unchanged model. The results are qualitatively unchanged against M 3 through M 5, but additional tests do not support the random-effects specification. ${ }^{15}$ In the light of these results, one may thus consider M 4 - which yields quantitatively the same results as M3 and M5 - as the final specification of the present TFP-in-levels estimation and use it as a baseline for further analyses.

13 The $F$-test on joint significance of all the $L$-variables rejects the Null hypothesis that they are all equal to zero with prob $>F=0.0015$ for model M 4a. With M 4b, the test statistic is prob $>F=0.0412$.

14 These effects are jointly significant at a 1-percent level in both versions of model M 5.

15 The Hausman test rejects that country-specific effects are uncorrelated with the other explanatory variables. The Breusch-Pagan test confirms that there is no autocorrelation in the country-specific effects. Both these results imply that the country-level effects are not randomly distributed. 
Table 1: The age composition of the labour force and TFP

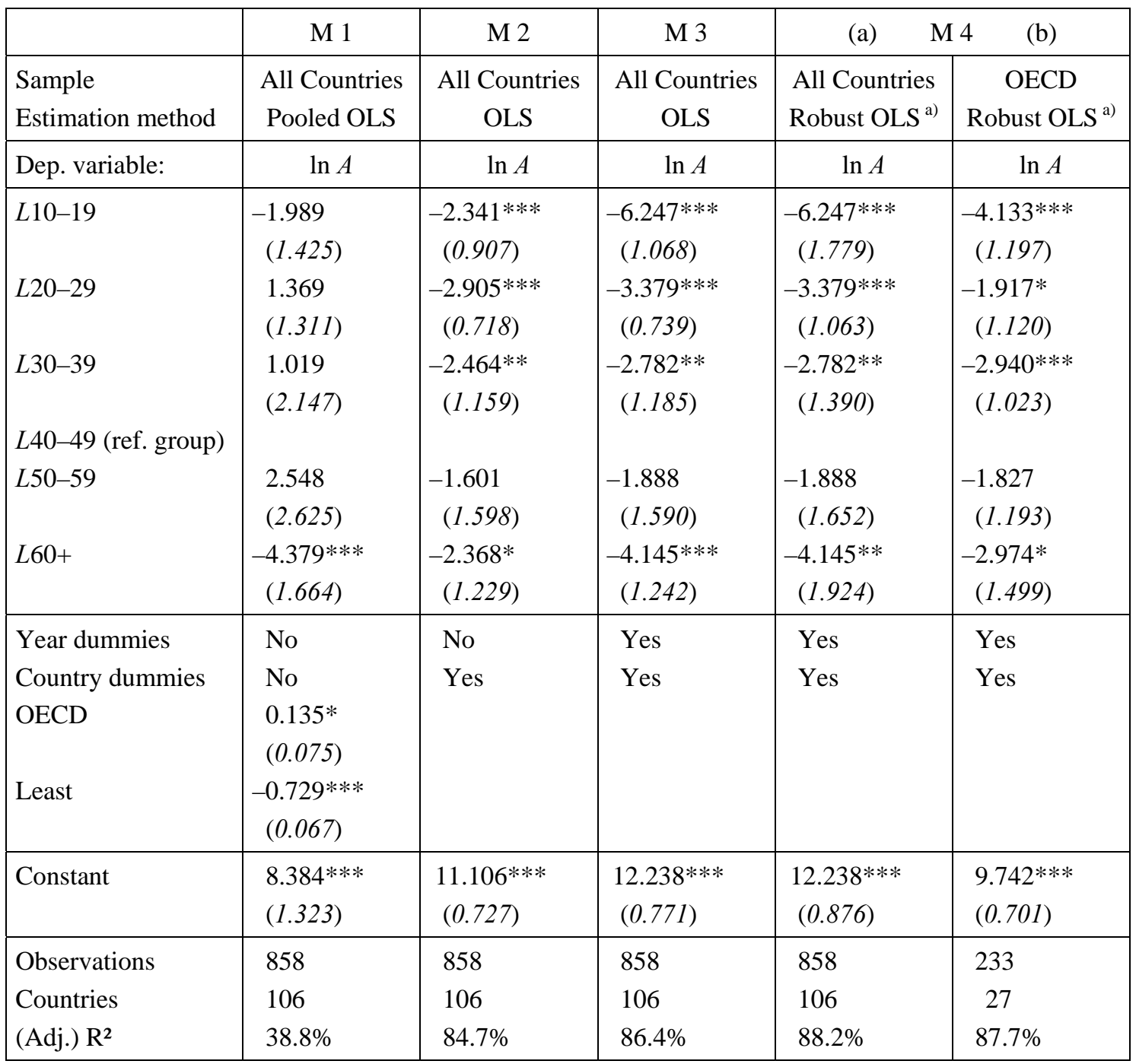

a) Residuals clustered by countries to avoid distortions of standard errors through serial correlation. $* * *, * *$ and $*$ denote significance at a 1-percent, 5-percent or 10-percent level, respectively. (Standard errors are in parentheses.)

Moving from level accounting to growth accounting in its original form, I then look at equation (7), investigating whether changes in the age composition of the labour force have an impact on TFP growth which is in line with the results derived from the levelequation (6). The new results are summarized in Table 2. Note that none of the estimations allows for a constant. M 7 also does not include country dummies and is thus equivalent to the baseline model M 4: the common assumption is that the trend growth rate is determined by the global technology frontier and is thus the same across countries, while labour-force demographics may speed up, or slow down, convergence. The alternative model with country dummies, M 8, allows for trend growth rates which per- 
Table 1 (cont'd.): The age composition of the labour force and TFP

\begin{tabular}{|c|c|c|c|c|}
\hline & (a) & (b) & (a) & (b) \\
\hline $\begin{array}{l}\text { Sample } \\
\text { Estimation method }\end{array}$ & $\begin{array}{c}\text { All Countries } \\
\text { OLS (fixed effects) }\end{array}$ & $\begin{array}{c}\text { OECD } \\
\text { OLS (fixed effects) }\end{array}$ & $\begin{array}{c}\text { All Countries } \\
\text { GLS (random eff.) }\end{array}$ & $\begin{array}{c}\text { OECD } \\
\text { GLS (random eff.) }\end{array}$ \\
\hline Dep. variable: & $\ln A$ & $\ln A$ & $\ln A$ & $\ln A$ \\
\hline L10-19 & $\begin{array}{c}-6.247^{* * *} \\
(1.068)\end{array}$ & $\begin{array}{l}-4.133^{* * *} \\
(1.017)\end{array}$ & $\begin{array}{c}-7.367 * * * \\
(0.964)\end{array}$ & $\begin{array}{c}-3.407 * * * \\
(0.966)\end{array}$ \\
\hline$L 20-29$ & $\begin{array}{c}-3.379 * * * \\
(0.739)\end{array}$ & $\begin{array}{l}-1.917^{* * *} \\
(0.609)\end{array}$ & $\begin{array}{c}-2.931^{* * *} \\
(0.750)\end{array}$ & $\begin{array}{l}-1.596^{* * *} \\
(0.619)\end{array}$ \\
\hline $\begin{array}{l}\text { L30-39 } \\
\text { L40-49 (ref. group) }\end{array}$ & $\begin{array}{c}-2.782 * * \\
(1.185)\end{array}$ & $\begin{array}{c}-2.940 * * * \\
(0.817)\end{array}$ & $\begin{array}{c}-3.098^{* * *} \\
(1.189)\end{array}$ & $\begin{array}{c}-2.606^{* * *} \\
(0.842)\end{array}$ \\
\hline$L 50-59$ & $\begin{array}{l}-1.888 \\
(1.590)\end{array}$ & $\begin{aligned}-1.827^{*} \\
(0.994)\end{aligned}$ & $\begin{array}{l}-2.158 \\
(1.592)\end{array}$ & $\begin{array}{l}-1.328 \\
(1.026)\end{array}$ \\
\hline L60+ & $\begin{array}{c}-4.145^{* * *} \\
(1.242)\end{array}$ & $\begin{array}{c}-2.974 * * * \\
(0.993)\end{array}$ & $\begin{array}{c}-5.008^{* * *} \\
(1.230)\end{array}$ & $\begin{array}{l}-2.761^{* * *} \\
(0.967)\end{array}$ \\
\hline Year dummies & Yes & Yes & Yes & Yes \\
\hline Constant & $\begin{array}{c}-11.625^{* * *} \\
(0.748)\end{array}$ & $\begin{array}{c}-10.915^{* * *} \\
(0.544)\end{array}$ & $\begin{array}{l}11.879 * * * \\
(0.754)\end{array}$ & $\begin{array}{l}10.571^{* * *} \\
(0.554)\end{array}$ \\
\hline Observations & 858 & 233 & 858 & 233 \\
\hline Countries & 106 & 27 & 106 & 27 \\
\hline $\mathrm{R}^{2}$ overall & $32.7 \%$ & $5.7 \%$ & $35.2 \%$ & $6.4 \%$ \\
\hline within & $14.5 \%$ & $40.6 \%$ & $14.1 \%$ & $40.4 \%$ \\
\hline between & $35.3 \%$ & $0.1 \%$ & $39.5 \%$ & $0.2 \%$ \\
\hline
\end{tabular}

$* * *, * *$ and * denote significance at a 1-percent, 5-percent or 10-percent level, respectively. (Standard errors are in parentheses.)

manently differ across countries, potentially giving demographics an additional role as a true driving force of technological progress, not merely a role for technology adoption.

Table 2 shows that the results of M 7 are basically in line with those of M 4. In the all-countries version of the estimation, three of the five $L$-variables are significant by themselves for explaining TFP growth, and they are jointly significant at a close-to-1percent level. ${ }^{16}$ Results for the OECD sub-sample are weaker in both respects, suggesting that demographics alone are less important for TFP growth in industrialized countries than they are in the rest of the world. Most importantly, however, the pattern of the $L$-coefficients, measuring the impact of the age composition of the labour force on the growth rate of TFP remains largely unchanged for both samples. Things are different

16 The $F$-test on joint significance of all the $L$-variables yields $p r o b>F=0.0153$ for model $\mathrm{M} 7 \mathrm{a}$ and prob $>F=0.1054$ for model M 7b. 
Table 2: Changes in the age composition of the labour force and TFP growth

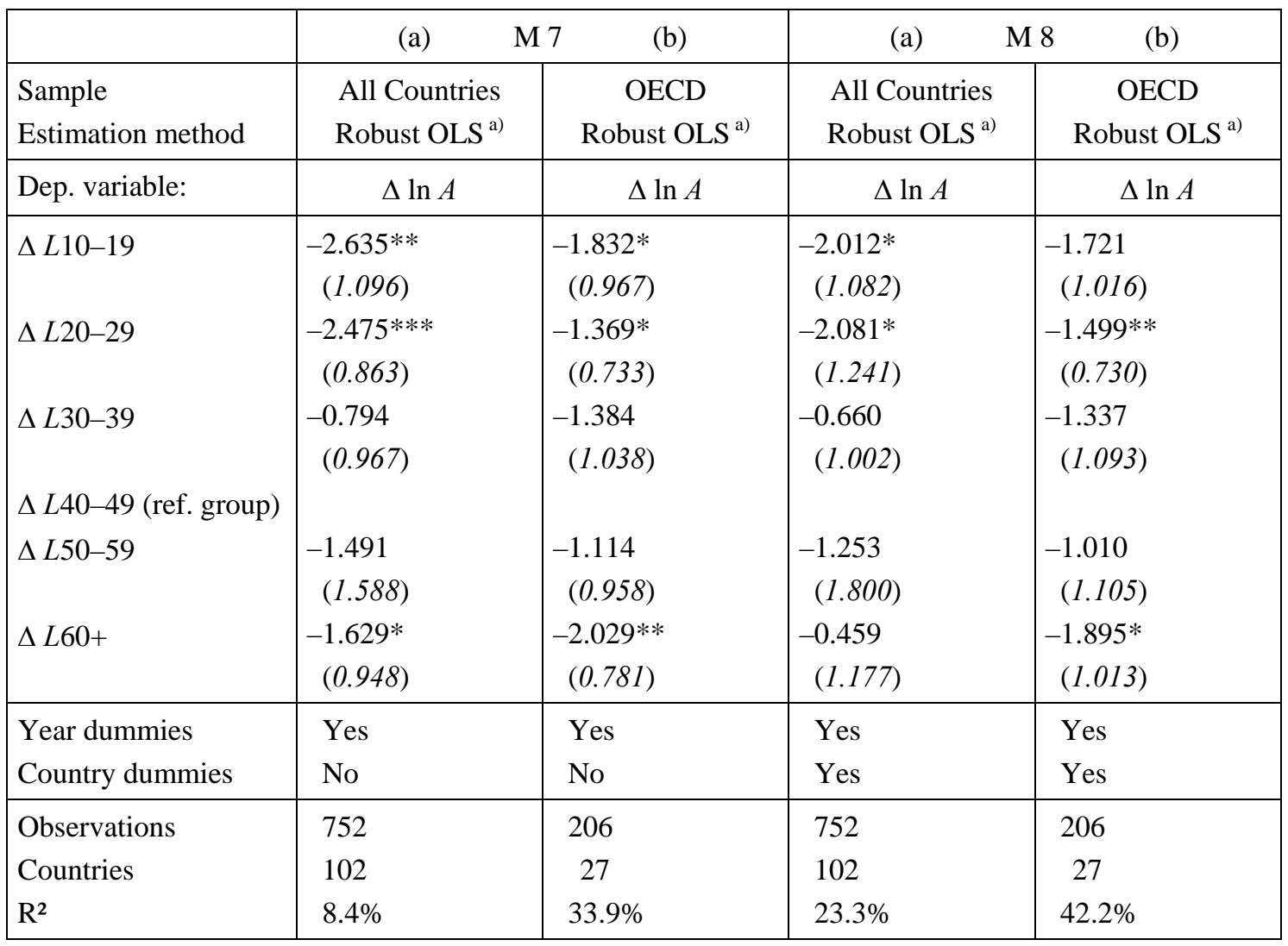

a) Residuals clustered by countries to avoid distortions of standard errors through serial correlation.

$* * *, * *$ and * denote significance at a 1-percent, 5-percent or 10-percent level, respectively. (Standard errors are in parentheses.)

with respect to $M 8$, the variant with country dummies. Here, the significance of estimates for the $L$-variables largely vanishes, and only in the OECD-variant the $L$-coefficients still exhibit a clear-cut, age-related pattern. At the same time, most of the country dummies turn out to be significant, but the overwhelming majority of the coefficients are in a very narrow band ranging from 0.1 to 0.2 in $\mathrm{M} \mathrm{8a}$, from 0.0 to 0.05 in $\mathrm{M} 8 \mathrm{~b}$. It appears that, once the impact of demographics on growth performance is controlled for, strong cross-country differences in trend growth rates are not supported by the data.

To put the results in a broader perspective and test for alternative channels of the impact of labour-force demographics on productivity and productivity growth, one could also use equations (3) and (4) and regress all of their components on the vector of $L$-variables. The results of these estimations are summarized in Tables 3 and $4 .{ }^{17}$ All of

17 The columns representing results for $\ln A$ and $\Delta \ln A$ in Tables 3 and 4 are identical with those of models M 4a, M 4b, M 7a and M 7b, respectively. 
Table 3: The composition of the impact of demographics on productivity

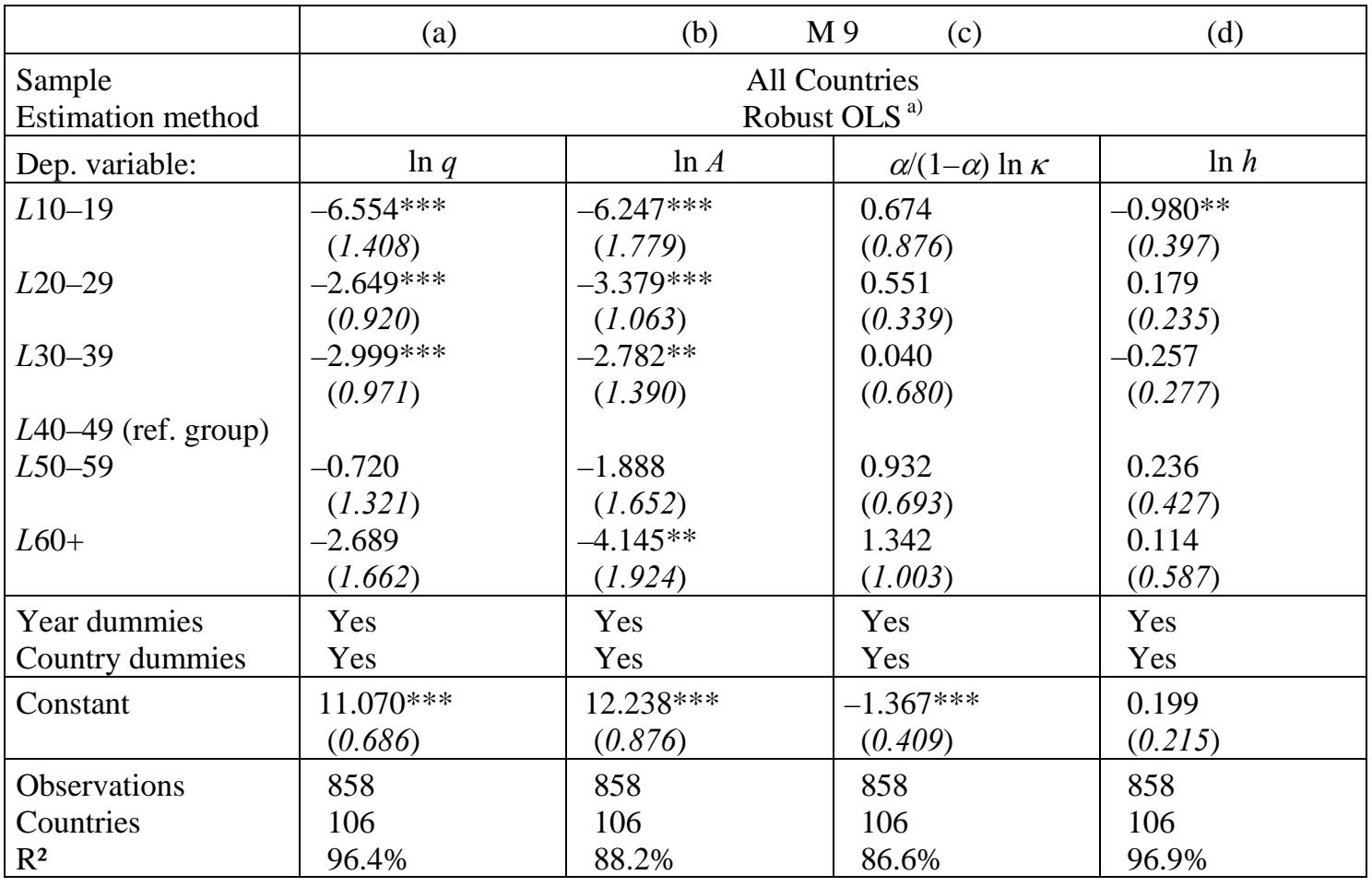

\begin{tabular}{|l|c|c|c|l|}
\hline & \multicolumn{1}{|c|}{ (e) } & \multicolumn{3}{c|}{ M 9 OECD } \\
Robust OLS
\end{tabular}

a) Residuals clustered by countries to avoid distortions of standard errors through serial correlation. ***, ** and $*$ denote significance at a 1-percent, 5-percent or 10-percent level, respectively. (Standard errors are in parentheses.) 
Table 4: The composition of the impact of demographics on productivity growth

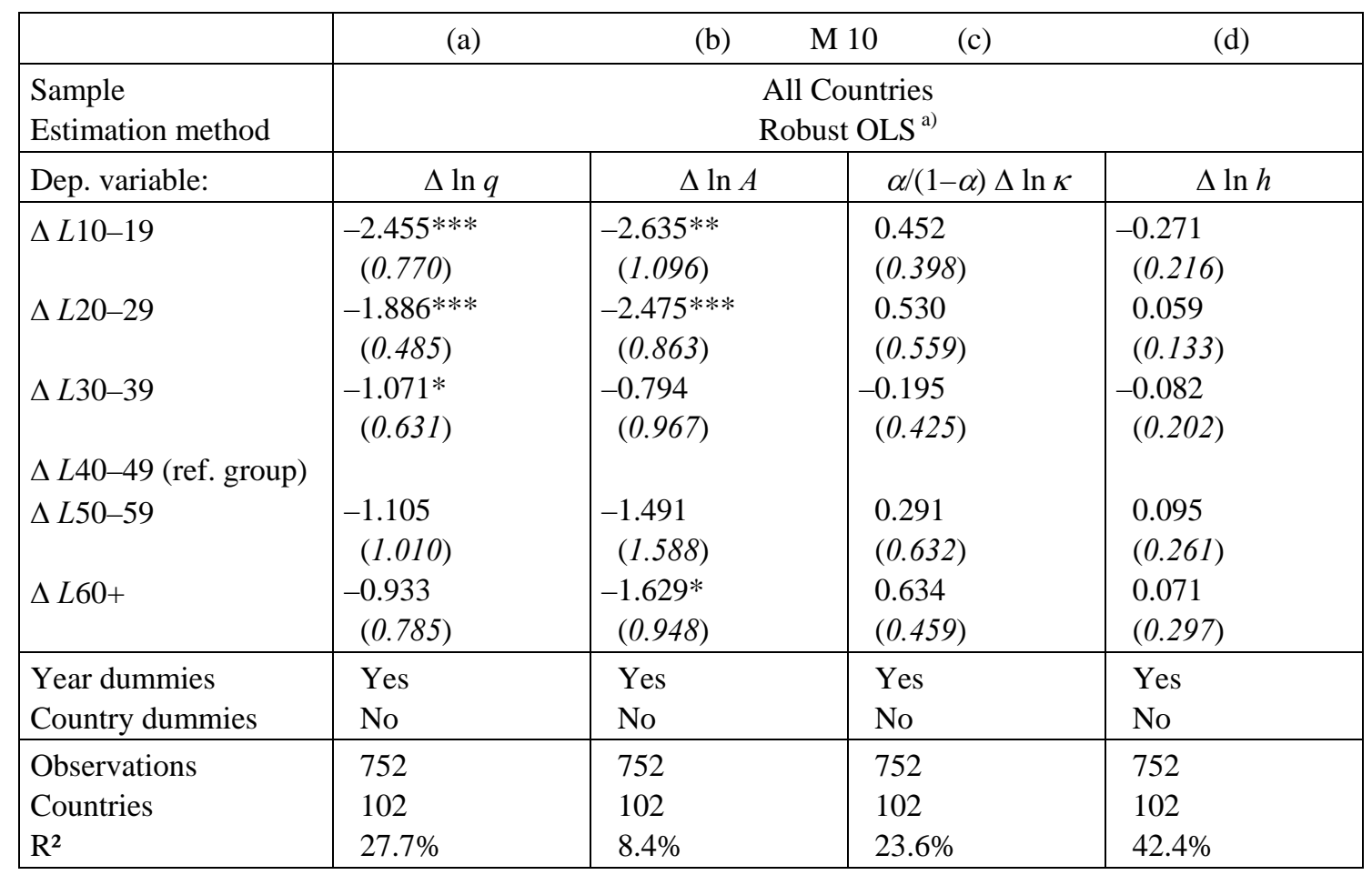

\begin{tabular}{|l|c|c|c|c|}
\hline & \multicolumn{5}{|c|}{$(\mathrm{e})$} & \multicolumn{3}{c|}{ (f) $10 \quad$ OECD } \\
Robust OLS
\end{tabular}

a) Residuals clustered by countries to avoid distortions of standard errors through serial correlation. $* * *, * *$ and $*$ denote significance at a 1-percent, 5-percent or 10-percent level, respectively. (Standard errors are in parentheses.) 
the findings reported there point to a first-order importance of the TFP channel for the observed impact of the age composition of the labour force on output per worker and its development over time. Note that, by construction, coefficients for $\ln q$ and $\Delta \ln q$ equal the sum of the coefficients related to $\ln A$ or $\Delta \ln A, \alpha /(1-\alpha) \ln \kappa$, etc.

It is easy to see that the $L$-coefficients related to TFP are always substantially larger than those related to the capital coefficient and human capital. Also, in the estimations for $\kappa$ and $h$, almost none of the $L$-coefficients are significant. In fact, they are all insignificant in model M10, i.e., for the variables in first differences. Only in the level-estimate for all countries, the age-structure variable relating to the youngest group of workers, $L 10-19$, yields a significant estimate with respect to the human-capital stock measure, $\ln h$. In the OECD-version, the same is true with respect to the capital coefficient, $\alpha /(1-\alpha) \ln \kappa$. In both cases, the coefficients are negative. The first of these results is easily understood. Outside the OECD world, labour-force participation of young adults is sometimes substantial, but this reduces the level of final educational attainments of the entire labour force. The second result points to a negative relationship between the size of the cohort who is just entering the labour force and the current capital coefficient which, in turn, contributes to a lower level of output per worker. Up to a point, this may reflect the "capital-dilution" effect of a growing labour force, probably the "baby boomers”, for productivity that was discussed in Section 2. In the current version of the model, there may thus be a limited influence of demographics on factor accumulation, as was also found by Brandner and Dowrick (1994) or Ahituv (2001), but it appears to be next to negligible vis-à-vis the strong impact on total factor productivity.

All in all, the findings thus far fully confirm the results obtained by Feyrer (2007), based on an up-dated sample and a longer time series, with ten years of additional data taken from a period in which, at least in develop countries, growth may have been much more regular than in the 1960s. A major result of the estimates is that the coefficients for $L 10-19$ through $L 60+$ exhibit a highly remarkable pattern. Age-related contributions to TFP and TFP growth clearly peak for workers in their 40s, as the coefficients for other age groups turn out to be negative. In the all-countries regressions, the overall pattern is in fact of a perfect, inverse $U$-shape, resembling that of a standard Mincertype wage regression. This is illustrated in Figure $1 .^{18}$ In the OECD-variant of M 4, the pattern is less pronounced in general, and there appears to be a deviation from the inverse $U$-shape related to those aged 20-29. (Note, however, that the point estimate is only borderline-significant in this case.) Thus, if one takes age-related wage profiles as

18 For a typical Mincerian wage regression, Figure 1 draws on results reported in Fenge et al. (2006), based on German micro-data. For illustrative purposes, the age-related relative contributions of each age group to the level of TFP are assessed based on the estimates derived from model M 4a above, using the year-2000 age structure of the German labour force. 
indicating age-specific productivity differentials that are observable at an individual level and can be internalized through wages, the structure of contributions of each age group to TFP exhibits a similar structure. Yet, the differential impact on TFP appears to be much stronger, pointing to quantitatively important "growth externalities" in an overall model of "transitory endogenous growth" by which the age composition of the entire labour force of a given country matters a lot for technology adoption and, hence, for levels and movements of total factor productivity.

Figure 1: Age-related wage profiles and age-specific contributions to TFP

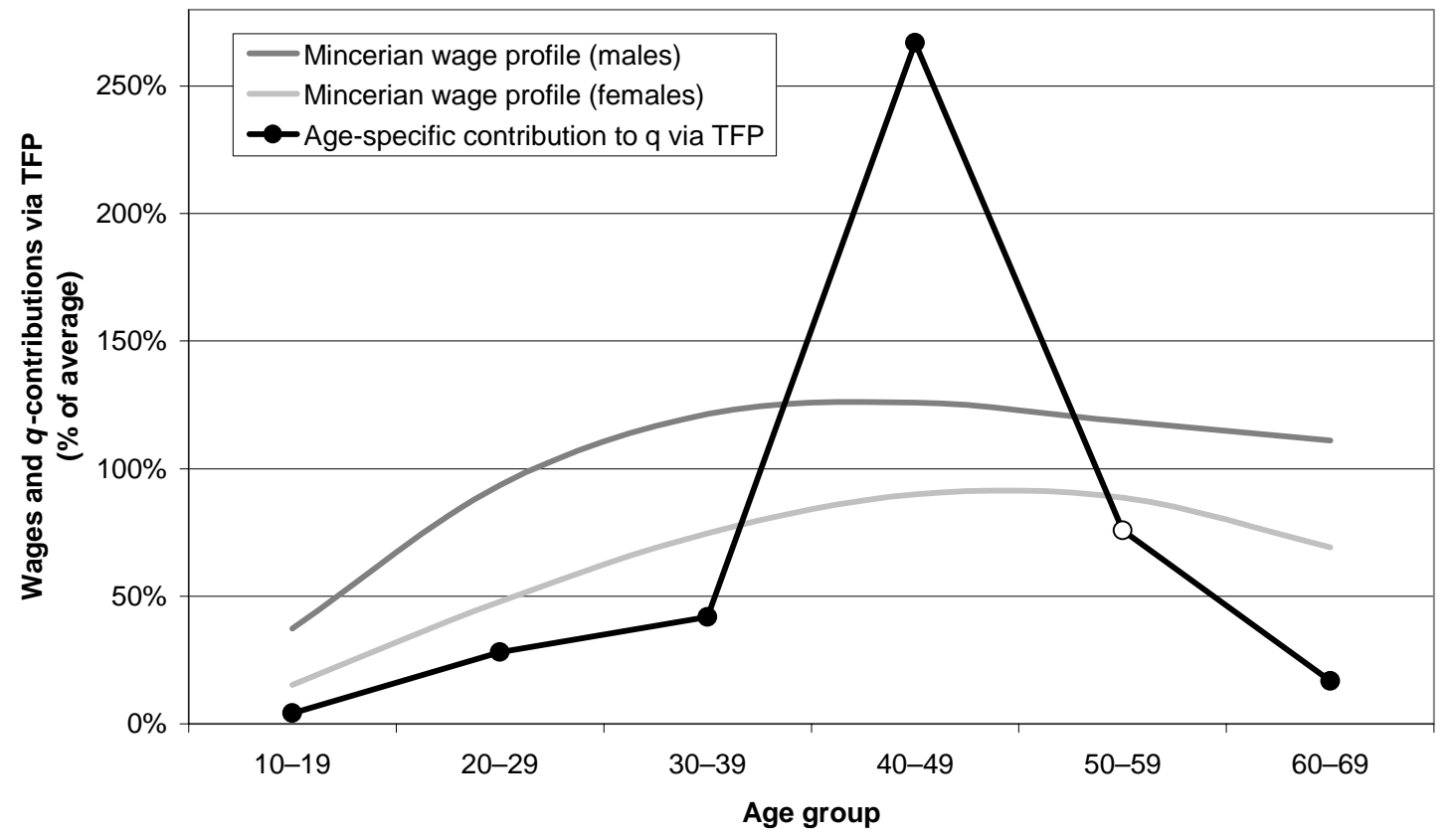

Sources: Fenge et al. (2006) for wage profiles; own calculations based on Model M 4a.

On the black curve, points representing the results of model $M$ 4a are filled if the underlying estimate is significant. The estimate for the 50-59 group is not significant.

\subsection{Extensions: Is there a role of cohort effects in human capital?}

For countries that are particularly hard hit by demographic ageing, the above estimates predict that expected changes in the age composition of the labour force may temporarily reduce trend TFP growth and trend productivity growth by more than 1 percentage point a year. In fact, the findings appear to be so strong and also robust that one might be happy to provide reasons why they could be exaggerated or even misleading. Some potential problems are already covered in Feyrer (2007). Here, I will briefly discuss some major potential sources of error, viz. endogeneity biases, measurement error regarding the dependent variable $A$ and an omitted-variable bias. Then, I will look into two of the issues that arise which could be really important. 
It has already been stated that, unlike many other potential determinants of economic growth, the $L$-regressors can be basically be considered to be exogenous, simply because they are to a very large extent determined by fertility decisions taken more than a decade ago. Yet, there could be endogenous features that matter for some important details. Migration is likely to respond to productivity and productivity growth, even though the role of recent migration for the age structure of the entire labour force of a given country may be limited. Also, labour-force participation may have an endogenous element, even if this need not affect the structure of the $L$-shares very much. Both these potential problems have already been investigated, and largely ruled out, by Feyrer (2007), using lagged variables and pure population shares as unbiased instruments. ${ }^{19}$

As the TFP-measure is determined residually, everything that is not properly accounted for when calculating it, i.e., everything not included in the $\kappa$ and $h$-terms in equation (3), is - probably wrongly - attributed to $A$. Here, two aspects of this wellknown problem may deserve a little more attention. First, productivity is defined on perworker terms throughout the above calculations. Therefore, if the average number of hours worked has declined over time this may create a distortion, mainly affecting calculated changes in TFP. Unfortunately, longer time series of data regarding this issue exist only for OECD countries where, at the same time, changes of this kind may have been most prominent over the last few decades. Again, it has already been demonstrated by Feyrer (2007) that controlling for these changes leaves the structure of coefficients, hence the estimated impact of labour-force demographics on TFP growth, unaffected. Second, in some countries not only the accumulation of physical and human capital, but also the exploitation of natural resources plays a major role for economic development, which may again distort the TFP-measure. As a prominent example, one may therefore use various definitions to identify oil-exporting countries and exclude them from the sample while re-doing the level-estimates based on model M 4. The results are basically unchanged against those reported in Table $1 .^{20}$

Finally, making the TFP residual $A$ dependent on the $L$-variables goes half way in the direction of the Lucas-Uzawa growth model, as I already noted. There is then one natural extension of the Feyrer (2007) framework which completes this analogy. Not

19 The latter findings are also in line with those of Lindh and Malmberg (1999); see Section 2.2.

20 See Appendix A.3. If anything, the age-related pattern of TFP-contributions becomes even more pronounced when more and more oil-exporting countries are dropped. Also, the results for the $L$-variables are jointly significant at the 1-percent level in all cases but the last one, where they are only close to being so. In this case, the definition of "oil-exporters" is extreme in that it encompasses all countries where, more than once in the 1960-2000 period, the share of fuel exports in total merchandise exports was in the top third of the annual global distribution of these shares. Since countries where foreigntrade data are lacking are also omitted, more than half of the observations are lost. Note that Feyrer (2007) uses a "non-oil” sample throughout, being more cautious in this respect than necessary. 
only the age structure of the labour force but also that of their human capital, that is, age-specific values of $h 10-19, h 20-29$, etc., might affect the TFP measure. In fact, since individuals well into their 20s are still in the process of accumulating human capital, while older workers often have lower final educational attainments than their successors, the entire age-related pattern of TFP contributions could therefore, at least partly, be driven by cohort effects located in educational attainments.

To investigate this idea more closely, data on educational attainments by age groups are needed that have the same coverage as the data panel I have been using. So far, data of this kind are nowhere provided directly. It is difficult, though possible, however, to re-cover such information from the Barro-Lee (2001) dataset I already used to account for human-capital accumulation. The data that result from a series of transformations ${ }^{21}$ have a number of limitations. Most importantly, they cannot reflect the full age-related variation of educational attainments for the entire sample period, as more and more entries for older age groups have to be set to uniform averages when moving backward in

${ }^{21}$ The data set on educational attainments constructed by Barro and Lee (2001) offers two series of results, one for the population aged 15 and above - which I have used in calculating $\ln h$ - and one for the population aged 25 and above. Educational attainments of those aged 15-24 should therefore be given by $h_{15-24}=\left(h_{15+} P_{o p_{15+}}-h_{25^{+}}\right.$Pop $\left._{25+}\right) /\left(\right.$ Pop $\left._{15-24}\right)$; detailed population data are taken from the UN Population Division's (2006) data base which shows only minimal deviations from the figures for $P_{o p_{15+}}$ and $P_{o p_{25+}}$ provided by Barro and Lee (2001). In line with the timing of human-capital accumulation assumed by Barro and Lee (2001, eq. (6)-(9), viz. that 15-19 year olds are beyond primary education, half way through secondary education and have no tertiary education; that 20-24-year olds are beyond secondary education and half way through tertiary education), one can infer final, or full, educational attainments of those currently aged 15-24 and consider these constant from age 25 on-

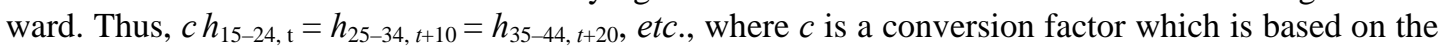
assumptions just mentioned and on the proportions of the relevant age groups. This yields a series of educational attainments by age groups which runs from 1960 to 2000 for those aged 15-24 but, unfortunately, covers those aged 55-64 only in the year 2000. In other words, relying on data resulting from these transformations only I would largely lose the time-series dimension.

To overcome this serious limitation without doing violence to the data that are in place, I therefore take a second step. Based on $h_{X^{+}}=\left(h_{15^{+}} P_{o p_{15+}}-h_{<X} P o p_{<X}\right) /\left(P_{o p_{X+}}\right)$ I impute adjusted figures for average educational attainments to all groups aged $X$ and above for which these data are missing. This certainly implies a loss in potential variation across age groups, but does not rely on any additional conjectures which might not be supported by the original data. Only, with the population measured in 1,000s and educational attainments measured as average years of schooling (differentiated by levels) with just one decimal digit, this procedure is susceptible to relatively large rounding errors, especially where average educational attainments are close to zero. I thus drop a limited number of results that are either implausibly low $(<-0.2)$ or exceed the highest figures observed for 2000. Remaining negative figures are set to zero. Note that, in general, rounding errors should produce noise, but generate no systematic biases. In any case, I will also use only non-imputed figures for robustness checks.

As the last step to take I switch from results for "odd" age groups (15-24 etc.) to "even” ones (10-19 etc.) in a straightforward way. Without making any further assumptions regarding cohort effects at the level of 5-year age groups, but taking into account the Barro-Lee assumptions regarding the standardized timing of human-capital accumulation, I use population-weighted averages of $h_{15-24}$ and $h_{25-34}$ etc. for adjacent age groups and determine the end points $h_{15-19}$ and $h_{60-64}$ residually. Finally, I take the latter two results to apply to workers aged 10-19 and 60+, respectively, as labour-force participation among those aged less than 15 or 65 and above is usually low. 
time. Also, the resulting data may effectively convey some noise, especially in the case of non-OECD countries where educational attainments are often low and formal education processes do not follow a strongly standardized timing. As a further limitation for any in-depth analysis, the number of observations I am using is limited from the out-set, definitely in the OECD sample, and therefore does not easily allow for introducing a multitude of additional regressors. To deal with this problem, I therefore run two series of regressions, one where I add a full set of age-specific human-capital variables ( $h 10$ 19 through $h 60+$ ) to the baseline models and one where I use each of these variables in turn, but only one at a time.

The $h$-variables are defined as age-specific educational attainments derived from the Barro and Lee (2001) data, converted into a comprehensive human-capital measure following Hall and Jones (1999). ${ }^{22}$ They are then divided by the average stock of human capital per worker in each country and year in order to remove correlations between them and to avoid that, when used in isolation, they are simply a proxy for average human capital. ${ }^{23}$ As a complement of the shares of each age group in the labour force captured by the regressors $L 10-19$ etc., the $h 10-19$ s etc. thus reflect the relative level of qualifications of individuals in any of these groups. Tables 5 and 6 report on the results of estimations which augment models M 4 and M 7 in the way just described. ${ }^{24}$

Models M 11 and M 12 which use age-specific measures of human capital as additional regressors essentially show two things. First, cohort effects in educational attainments appear to play some role in determining both TFP levels and TFP growth. But second, they never make the strong age-related pattern of the $L$-coefficients disappear. When the $h$-variables are thrown in, the age profile for the $L$-variables becomes less pronounced but, at the same time, gets a bit sharper in terms of significance. ${ }^{25}$ By them selves, the -coefficients show no clear, age-related pattern. Yet, taken in isolation, they are jointly significant in the growth-estimates in models $\mathrm{M} 11 \mathrm{~h}$ and $\mathrm{M} 12 \mathrm{~h}$ and there are also a number of significant estimates for human capital of single age groups.

22 See footnote 21 on the way the Barro-Lee data are being used and footnote 10 for further details regarding the human-capital measure suggested by Hall and Jones (1999).

23 Regressions on human-capital data without this normalization do not look very different.

24 For comparison, Appendix A.4 lists the results for Models M 4 and M 7 when, in each case, the sample is restricted to observations which also enter the human-capital augmented regressions. Also, as one may doubt the validity of the imputations of missing human-capital data explained in footnote 21, Appendix A.5 reports on parallel regressions using only non-imputed data. To the extent that these results can be compared at all to those provided in Tables 5 and 6, they are much in line with them.

25 This can be seen by comparing M 11 and M 12 to their counterparts in Appendix A.4. The L-coefficients are jointly significant in all of the models M 11a, M 11h, M 12a and M 12h (with prob > $F=0.0214$, prob $>F=0.0838$, prob $>F=0.0360$ and prob $>F=0.0353$, respectively). They are also jointly significant in models M 4g, M 7c and M 7d (with prob $>F=0.0238$, prob $>F=0.0480$ and prob $>F=0.0666$, respectively), but not in $\mathrm{M} 4 \mathrm{~h}$. 
Table 5: The age distribution of human capital and TFP

\begin{tabular}{|c|c|c|c|c|c|c|c|}
\hline & (a) & (b) & (c) & M 11 (d) & (e) & (f) & (g) \\
\hline $\begin{array}{l}\text { Sample } \\
\text { Estim. Method }\end{array}$ & \multicolumn{7}{|c|}{$\begin{array}{l}\text { All countries } \\
\text { Robust OLS }{ }^{\text {a) }}\end{array}$} \\
\hline Dep. variable: & $\ln A$ & $\ln A$ & $\ln A$ & $\ln A$ & $\ln A$ & $\ln A$ & $\ln A$ \\
\hline L10-19 & $\begin{array}{c}-5.717^{* * *} \\
(1.923)\end{array}$ & $\begin{array}{c}-6.184^{* * *} \\
(1.849)\end{array}$ & $\begin{array}{c}-6.260^{* * *} \\
(1.914)\end{array}$ & $\begin{array}{c}-6.470^{* * *} \\
(1.805)\end{array}$ & $\begin{array}{c}-6.329 * * * \\
(1.821)\end{array}$ & $\begin{array}{c}-6.208^{* * *} \\
(1.884)\end{array}$ & $\begin{array}{c}-6.075^{* * *} \\
(1.933)\end{array}$ \\
\hline L20-29 & $\begin{array}{c}-2.659 * * \\
(1.247)\end{array}$ & $\begin{array}{c}-3.219 * * * \\
(1.089)\end{array}$ & $\begin{array}{c}-3.358^{* * *} \\
(1.129)\end{array}$ & $\begin{array}{c}-3.537 * * * \\
(1.028)\end{array}$ & $\begin{array}{c}-3.480^{* * *} \\
(1.096)\end{array}$ & $\begin{array}{c}-3.253^{* * *} \\
(1.189)\end{array}$ & $\begin{array}{c}-3.332 * * * \\
(1.212)\end{array}$ \\
\hline $\begin{array}{l}\text { L30-39 } \\
\text { L40-49 (ref. gr.) }\end{array}$ & $\begin{array}{c}-1.803 \\
(1.746)\end{array}$ & $\begin{array}{c}-2.838 * * \\
(1.430)\end{array}$ & $\begin{array}{r}-2.836^{*} \\
(1.488)\end{array}$ & $\begin{array}{c}-2.941^{* *} \\
(1.422)\end{array}$ & $\begin{array}{c}-2.812^{* *} \\
(1.391)\end{array}$ & $\begin{array}{l}-2.484 \\
(1.705)\end{array}$ & $\begin{array}{c}-2.229 \\
(1.654)\end{array}$ \\
\hline$L 50-59$ & $\begin{array}{l}-1.536 \\
(1.952)\end{array}$ & $\begin{array}{l}-2.157 \\
(1.787)\end{array}$ & $\begin{array}{l}-2.111 \\
(1.761)\end{array}$ & $\begin{array}{l}-2.224 \\
(1.788)\end{array}$ & $\begin{array}{l}-1.797 \\
(1.751)\end{array}$ & $\begin{array}{l}-1.968 \\
(1.714)\end{array}$ & $\begin{array}{l}-1.874 \\
(1.820)\end{array}$ \\
\hline L60+ & $\begin{array}{r}-2.945 \\
(2.157) \\
\end{array}$ & $\begin{array}{l}-3.396 \\
(2.122) \\
\end{array}$ & $\begin{array}{l}-3.591 \\
(2.235) \\
\end{array}$ & $\begin{array}{r}-3.830 * \\
(2.042) \\
\end{array}$ & $\begin{array}{c}-4.226 * * \\
(2.000)\end{array}$ & $\begin{array}{r}-3.735 * \\
(2.122)\end{array}$ & $\begin{array}{r}-3.550 * \\
(2.065)\end{array}$ \\
\hline h10-19 & $\begin{array}{c}-0.456 \\
(0.282)\end{array}$ & $\begin{array}{l}0.086 \\
(0.096)\end{array}$ & & & & & \\
\hline$h 20-29$ & $\begin{array}{l}1.425^{* *} \\
(0.618)\end{array}$ & & $\begin{array}{l}0.157 \\
(0.156)\end{array}$ & & & & \\
\hline h30-39 & $\begin{array}{c}-1.464^{* *} \\
(0.735)\end{array}$ & & & $\begin{array}{l}-0.003 \\
(0.158)\end{array}$ & & & \\
\hline$h 40-49$ & $\begin{array}{l}1.330^{* *} \\
(0.588)\end{array}$ & & & & $\begin{array}{l}0.070 \\
(0.108)\end{array}$ & & \\
\hline$h 50-59$ & $\begin{array}{l}-0.731 \\
(0.446)\end{array}$ & & & & & $\begin{array}{l}-0.006 \\
(0.097)\end{array}$ & \\
\hline$h 60+$ & $\begin{array}{l}0.187 \\
(0.145)\end{array}$ & & & & & & $\begin{array}{l}-0.045 \\
(0.066)\end{array}$ \\
\hline Year dummies & Yes & Yes & Yes & Yes & Yes & Yes & Yes \\
\hline Ctry. dummies & Yes & Yes & Yes & Yes & Yes & Yes & Yes \\
\hline Constant & $\begin{array}{c}11.067 * * * \\
(1.183)\end{array}$ & $\begin{array}{c}12.026 * * * \\
(0.874)\end{array}$ & $\begin{array}{c}11.951^{* * *} \\
(1.099)\end{array}$ & $\begin{array}{c}12.379 * * * \\
(1.014)\end{array}$ & $\begin{array}{c}12.223^{* * *} \\
(0.926)\end{array}$ & $\begin{array}{c}12.118^{* * *} \\
(1.003)\end{array}$ & $\begin{array}{c}12.042^{* * *} \\
(1.069)\end{array}$ \\
\hline Observations & 815 & 823 & 823 & 835 & 841 & 834 & 831 \\
\hline Countries & 103 & 103 & 103 & 103 & 103 & 103 & 103 \\
\hline $\mathrm{R}^{2}$ & $88.1 \%$ & $87.6 \%$ & $87.6 \%$ & $87.6 \%$ & $87.7 \%$ & $87.8 \%$ & $87.9 \%$ \\
\hline
\end{tabular}

a) Residuals clustered by countries to avoid distortions of standard errors through serial correlation. ***, ** and * denote significance at a 1-percent, 5-percent or 10-percent level, respectively. (Standard errors are in parentheses.) 
Table 5 (cont'd.): The age distribution of human capital and TFP

\begin{tabular}{|c|c|c|c|c|c|c|c|}
\hline & (h) & (i) & (j) & M $11(\mathrm{k})$ & (l) & (m) & (n) \\
\hline $\begin{array}{l}\text { Sample } \\
\text { Estim. Method }\end{array}$ & \multicolumn{7}{|c|}{$\begin{array}{c}\text { OECD } \\
\text { Robust OLS }{ }^{\text {a) }}\end{array}$} \\
\hline Dep. variable: & $\ln A$ & $\ln A$ & $\ln A$ & $\ln A$ & $\ln A$ & $\ln A$ & $\ln A$ \\
\hline L10-19 & $\begin{array}{c}-4.455^{* * *} \\
(1.308)\end{array}$ & $\begin{array}{c}-4.299 * * * \\
(1.237)\end{array}$ & $\begin{array}{c}-4.429 * * * \\
(1.389)\end{array}$ & \begin{tabular}{|c|}
$-4.014^{* * *}$ \\
$(1.210)$
\end{tabular} & $\begin{array}{c}-4.107^{* * *} \\
(1.250)\end{array}$ & $\begin{array}{c}-4.230^{* * *} \\
(1.341)\end{array}$ & $\begin{array}{c}-3.990^{* * *} \\
(1.163)\end{array}$ \\
\hline L20-29 & $\begin{array}{r}-2.185^{*} \\
(1.162)\end{array}$ & \begin{tabular}{|}
$-2.066^{*}$ \\
$(1.154)$
\end{tabular} & $\begin{array}{r}-2.083^{*} \\
(1.185)\end{array}$ & $\begin{array}{c}-1.901 \\
(1.118)\end{array}$ & $\begin{array}{c}-1.894 \\
(1.113)\end{array}$ & \begin{tabular}{|c|}
-1.942 \\
$(1.158)$
\end{tabular} & $\begin{array}{c}-1.888 \\
(1.112)\end{array}$ \\
\hline $\begin{array}{l}\text { L30-39 } \\
\text { L40-49 (ref. gr.) }\end{array}$ & $\begin{array}{c}-3.336 * * * \\
(0.999)\end{array}$ & $\begin{array}{c}-3.110^{* * *} \\
(1.072)\end{array}$ & $\begin{array}{c}-3.205^{* * *} \\
(1.128)\end{array}$ & $\begin{array}{c}-2.892^{* *} \\
(1.055)\end{array}$ & $\begin{array}{c}-2.850 * * \\
(1.049)\end{array}$ & $\begin{array}{c}-2.993^{* * *} \\
(1.078)\end{array}$ & $\begin{array}{c}-2.823^{* * *} \\
(1.000)\end{array}$ \\
\hline$L 50-59$ & $\begin{array}{c}-2.565^{* *} \\
(1.133)\end{array}$ & $\begin{array}{r}-2.273^{*} \\
(1.241)\end{array}$ & $\begin{array}{l}-2.935 \\
(1.780)\end{array}$ & $\begin{array}{l}-1.976 \\
(1.272)\end{array}$ & $\begin{array}{l}-1.756 \\
(1.176)\end{array}$ & $\begin{array}{r}-2.125^{*} \\
(1.209)\end{array}$ & $\begin{array}{l}-1.927 \\
(1.200)\end{array}$ \\
\hline$L 60+$ & $\begin{array}{c}-3.095 \\
(1.842)\end{array}$ & $\begin{array}{l}-2.869 \\
(1.739)\end{array}$ & $\begin{array}{l}-2.935 \\
(1.800) \\
\end{array}$ & $\begin{array}{l}-2.731 \\
(1.737)\end{array}$ & $\begin{array}{r}-3.063^{*} \\
(1.653)\end{array}$ & $\begin{array}{r}-2.968^{*} \\
(1.690)\end{array}$ & $\begin{array}{l}-2.746 \\
(1.671)\end{array}$ \\
\hline$h 10-19$ & $\begin{array}{l}0.202 \\
(0.230)\end{array}$ & $\begin{array}{l}-0.089 \\
(0.064)\end{array}$ & & & & & \\
\hline$h 20-29$ & $\begin{array}{c}-0.525 \\
(0.546)\end{array}$ & & $\begin{array}{l}-0.074 \\
(0.180)\end{array}$ & & & & \\
\hline h30-39 & $\begin{array}{l}0.796 \\
(0.635)\end{array}$ & & & $\begin{array}{l}0.128 \\
(0.118)\end{array}$ & & & \\
\hline$h 40-49$ & $\begin{array}{c}-0.718 \\
(0.563)\end{array}$ & & & & $\begin{array}{l}0.157 \\
(0.125)\end{array}$ & & \\
\hline$h 50-59$ & $\begin{array}{l}0.697 \\
(0.449)\end{array}$ & & & & & $\begin{array}{l}0.096 \\
(0.112)\end{array}$ & \\
\hline$h 60+$ & $\begin{array}{c}-0.220 \\
(0.176)\end{array}$ & & & & & & $\begin{array}{l}-0.030 \\
(0.061)\end{array}$ \\
\hline Year dummies & Yes & Yes & Yes & Yes & Yes & Yes & Yes \\
\hline Ctry. Dummies & Yes & Yes & Yes & Yes & Yes & Yes & Yes \\
\hline Constant & $\begin{array}{c}11.016^{* * *} \\
(0.849)\end{array}$ & $\begin{array}{c}11.217^{* * *} \\
(0.732)\end{array}$ & $\begin{array}{c}10.947 * * * \\
(0.874)\end{array}$ & $\begin{array}{c}10.109 * * * \\
(0.725)\end{array}$ & $\begin{array}{l}9.570^{* * *} \\
(0.677)\end{array}$ & $\begin{array}{c}10.939 * * * \\
(0.737)\end{array}$ & $\begin{array}{c}10.923 * * * \\
(0.706)\end{array}$ \\
\hline Observations & 217 & 219 & 219 & 225 & 231 & 228 & 228 \\
\hline Countries & 27 & 27 & 27 & 27 & 27 & 27 & 27 \\
\hline $\mathrm{R}^{2}$ & $88.0 \%$ & $88.0 \%$ & $87.8 \%$ & $87.8 \%$ & $88.1 \%$ & $87.7 \%$ & $87.7 \%$ \\
\hline
\end{tabular}

a) Residuals clustered by countries to avoid distortions of standard errors through serial correlation. $* * *, * *$ and $*$ denote significance at a 1-percent, 5-percent or 10-percent level, respectively. (Standard errors are in parentheses.) 
Table 6: Changes in the age distribution of human capital and TFP growth

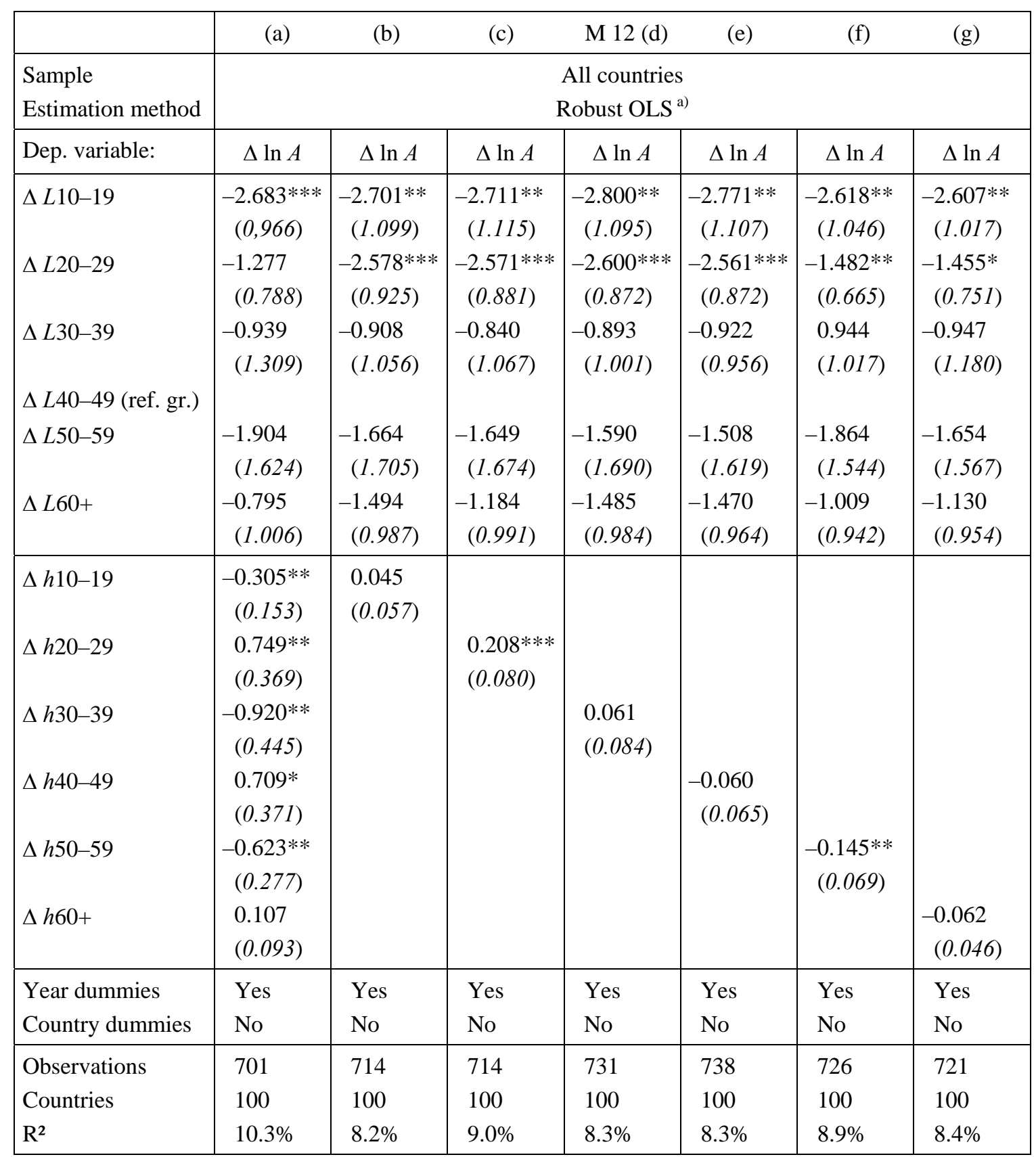

a) Residuals clustered by countries to avoid distortions of standard errors through serial correlation. $* * *, * *$ and * denote significance at a 1-percent, 5-percent or 10-percent level, respectively. (Standard errors are in parentheses.) 
Table 6 (cont'd.): Changes in the age distribution of human capital and TFP growth

\begin{tabular}{|c|c|c|c|c|c|c|c|}
\hline & (h) & (i) & (j) & M $12(\mathrm{k})$ & (l) & (m) & (n) \\
\hline $\begin{array}{l}\text { Sample } \\
\text { Estimation method }\end{array}$ & \multicolumn{7}{|c|}{$\begin{array}{c}\text { OECD } \\
\text { Robust OLS }\end{array}$} \\
\hline Dep. variable: & $\Delta \ln A$ & $\Delta \ln A$ & $\Delta \ln A$ & $\Delta \ln A$ & $\Delta \ln A$ & $\Delta \ln A$ & $\Delta \ln A$ \\
\hline$\Delta L 10-19$ & $\begin{array}{l}-1.586 \\
(0.940)\end{array}$ & $\begin{array}{c}-2.063 * * \\
(0.994)\end{array}$ & $\begin{array}{l}-1.553 \\
(1.096)\end{array}$ & $\begin{array}{r}-1.673^{*} \\
(0.946)\end{array}$ & $\begin{array}{r}-1.752 * \\
(1.024)\end{array}$ & $\begin{array}{l}-1.452 \\
(0.955)\end{array}$ & $\begin{array}{l}-1.524 \\
(0.916)\end{array}$ \\
\hline$\Delta L 20-29$ & $\begin{array}{c}-1.498^{* *} \\
(0.714)\end{array}$ & $\begin{array}{r}-1.546 * \\
(0.764)\end{array}$ & $\begin{array}{r}-1.314^{*} \\
(0.763)\end{array}$ & $\begin{array}{l}-1.235 \\
(0.747)\end{array}$ & $\begin{array}{l}-1.280 \\
(0.769)\end{array}$ & $\begin{array}{l}-1.238 \\
(0.752)\end{array}$ & $\begin{array}{r}-1.309 * \\
(0.730)\end{array}$ \\
\hline$\Delta L 30-39$ & $\begin{array}{r}-1.474^{*} \\
(0.889)\end{array}$ & $\begin{array}{l}-1.786 \\
(1.097)\end{array}$ & $\begin{array}{l}-1.568 \\
(1.141)\end{array}$ & $\begin{array}{l}-1.374 \\
(1.080)\end{array}$ & $\begin{array}{l}-1.333 \\
(1.056)\end{array}$ & $\begin{array}{l}-1.153 \\
(0.965)\end{array}$ & $\begin{array}{l}-1.111 \\
(0.933)\end{array}$ \\
\hline$\Delta L 40-49$ (ref. gr.) & & & & & & & \\
\hline$\Delta L 50-59$ & $\begin{array}{l}-1.346 \\
(0.908)\end{array}$ & $\begin{array}{l}-1.688 \\
(1.006)\end{array}$ & $\begin{array}{l}-1.437 \\
(1.033)\end{array}$ & $\begin{array}{l}-1.258 \\
(0.997)\end{array}$ & $\begin{array}{l}-1.101 \\
(0.973)\end{array}$ & $\begin{array}{l}-0.918 \\
(0.900)\end{array}$ & $\begin{array}{l}-0.900 \\
(0.896)\end{array}$ \\
\hline$\Delta L 60+$ & $\begin{array}{c}-1.308 \\
(0.781) \\
\end{array}$ & $\begin{array}{c}-1.632^{* *} \\
(0.763) \\
\end{array}$ & $\begin{array}{r}-1.303 \\
(0.866) \\
\end{array}$ & $\begin{array}{r}-1.403^{*} \\
(0.767) \\
\end{array}$ & $\begin{array}{c}-1.760 * * \\
(0.800) \\
\end{array}$ & $\begin{array}{c}-1.539 * * \\
(1.924) \\
\end{array}$ & $\begin{array}{c}-1.636^{* *} \\
(0.704) \\
\end{array}$ \\
\hline$\Delta h 10-19$ & $\begin{array}{l}-0.043 \\
(0.168)\end{array}$ & $\begin{array}{l}-0.090 \\
(0.064)\end{array}$ & & & & & \\
\hline$\Delta h 20-29$ & $\begin{array}{l}0.022 \\
(0.414)\end{array}$ & & $\begin{array}{l}0.241^{* *} \\
(0.093)\end{array}$ & & & & \\
\hline$\Delta h 30-39$ & $\begin{array}{l}0.141 \\
(0.444)\end{array}$ & & & $\begin{array}{l}0.174^{*} \\
(0.092)\end{array}$ & & & \\
\hline$\Delta h 40-49$ & $\begin{array}{l}-0.240 \\
(0.487)\end{array}$ & & & & $\begin{array}{l}-0.006 \\
(0.077)\end{array}$ & & \\
\hline$\Delta h 50-59$ & $\begin{array}{l}0.137 \\
(0.341)\end{array}$ & & & & & $\begin{array}{c}-0.128^{* *} \\
(0.058)\end{array}$ & \\
\hline$\Delta h 60+$ & $\begin{array}{l}-0.097 \\
(0.138)\end{array}$ & & & & & & $\begin{array}{c}-0.051 \\
(0.038)\end{array}$ \\
\hline $\begin{array}{l}\text { Year dummies } \\
\text { Country dummies }\end{array}$ & $\begin{array}{l}\text { Yes } \\
\text { No }\end{array}$ & $\begin{array}{l}\text { Yes } \\
\text { No }\end{array}$ & $\begin{array}{l}\text { Yes } \\
\text { No }\end{array}$ & $\begin{array}{l}\text { Yes } \\
\text { No }\end{array}$ & $\begin{array}{l}\text { Yes } \\
\text { No }\end{array}$ & $\begin{array}{l}\text { Yes } \\
\text { No }\end{array}$ & $\begin{array}{l}\text { Yes } \\
\text { No }\end{array}$ \\
\hline Observations & 185 & 188 & 188 & 197 & 204 & 199 & 199 \\
\hline Countries & 26 & 26 & 26 & 26 & 26 & 26 & 26 \\
\hline $\mathrm{R}^{2}$ & $38.9 \%$ & $34.8 \%$ & $35.7 \%$ & $33.7 \%$ & $32.0 \%$ & $34.5 \%$ & $34.3 \%$ \\
\hline
\end{tabular}

a) Residuals clustered by countries to avoid distortions of standard errors through serial correlation. $* * *, * *$ and $*$ denote significance at a 1-percent, 5-percent or 10-percent level, respectively. (Standard errors are in parentheses.) 
The regressions bundled in Tables 5 and 6 should be read as follows. The columns where all the $h$-variables are present are what I really want to look at. Due to the relatively large number of regressors, however, significance and (insignificant) signs of the estimates may be obscured. The additional regressions, each with just one $h$-variable, may therefore serve as robustness checks. Only if results for the $h$ s of single age groups are basically the same in both cases, they may be fully trustworthy. Also, because of the smaller number of observations, the models generally perform weaker for OECD countries than they do for the all-countries sample. Besides the finding that the age structure of human capital may generally matter for TFP and TFP growth, this leaves us with a potentially positive effect relating to human capital of workers in their 20s and a potentially negative effect for workers in their 50s. By the definition of $h 10-19$ etc., these results are difficult to interpret, certainly with respect to TFP-levels. Yet, they may reflect that relatively high qualifications of younger workers, with those aged 25 usually reaching their final level of educational attainments, point to a current improvement in human capital; relatively high qualifications of older workers result from a (temporary) decline in educational attainments of new labour-market entrants which has been observed in a number of developing countries, especially among former colonies.

Up to a point, these extensions beyond purely demographic effects are therefore instructive in themselves. In the final analysis, however, they mainly reinforce that there is a strong impact, with a particular age-related shape, of labour-force demographics on TFP, labour productivity and, hence, on economic growth in general, as was already shown in Section 4.1.

\section{Conclusions}

In this paper, I have taken a closer look at the potential impact of (changes in) the age composition of the labour force, hence (changes in) past fertility rates, on the growth performance in a long, multi-country data panel. Building on the limited amount of existing literature that attempts to address this issue in an empirical framework, I found an effect that appears to be surprisingly strong, affecting productivity and productivity growth, and therefore goes beyond the simple arithmetic of changes in population size and dependency ratios. More specifically, the age composition of a given country's labour force appears to affect total factor productivity (TFP) and its growth, which are generally observed to be the most important sources of variation in economic performance in the empirical growth literature. The effect thus assumes the features of a phenomenon of (transitory) endogenous growth.

An interesting aspect is that the age-related profile of contributions to TFP implies that workers in the age group 40-49 are most important for attaining high levels and 
faster growth of productivity, while the contributions of younger and older workers are considerably smaller. In other words, the particular age profile reflected in Mincerian wage regressions, which is usually taken to reflect productivity differentials related to age or experience, could feed through to TFP through externalities in the invention or, probably even more so, in the adoption and utilization of new technologies. This effect is indeed much stronger than anything that can be observed at the micro level. Closer inspection reveals that cohort effects in educational attainments may contribute, to some extent, to shaping this particular age-related pattern. But basically, it does not appear to be driven by the age structure of human capital.

Demographics exhibit a substantial amount of variation, both over time and across countries, even if one limits attention to the small group of highly developed countries. This will become even more apparent in the period of overt demographic ageing that is currently about to begin, with large cohorts of workers entering retirement and much smaller cohorts entering activity or moving to their prime age. The foregoing econometric analyses can therefore be complemented with a number of illustrative simulations which show how economic development could be influenced by future demographic change in the US, Japan, Germany, the UK, and France, i.e., the five largest OECD economies in terms of GDP where expected changes in the structure of the labour force as well as the entire population are rather diverse. The estimates based on model M 7 imply that changes in age composition of the labour force lead to deviations from TFP trend growth at a national level, while trend growth as such is basically the same across all countries. Using the results obtained for model M 7b (referring to the OECD sample), I can therefore simulate predicted deviations from trend productivity growth implied in current demographic projections (combined with current age-specific participation rates which are simply held constant) over the next four decades. ${ }^{26}$ I can then combine the results with aggregate figures for employment and total population implied in the same projections to translate them into predicted deviations from aggregate trend growth and trend growth per capita. The results are illustrated in Figure 2, spanning the time period from 1990 to 2050 to see how the predictions relate to actual developments over the last fifteen years.

According to these simulations, the five countries considered are likely to be affected by changes in the age composition of their labour force in different ways. As to

26 Population data and projections are taken from the 2006 release of the "World Population Prospects" prepared by the UN Population Division (2007, “constant-fertility” variant). Information regarding current activity rates is taken from the ILO (2007) LABORSTA database. Note that simulations derived from the all-countries regression in model M 7a would not be altogether different. Only, due to stronger variation in the $L$-coefficients, the profiles obtained would be even more pronounced than in the OECD variant which is used for Figure 2. 
Figure 2: The impact of projected demographic change on economic growth (1990-2050) - OECD regression
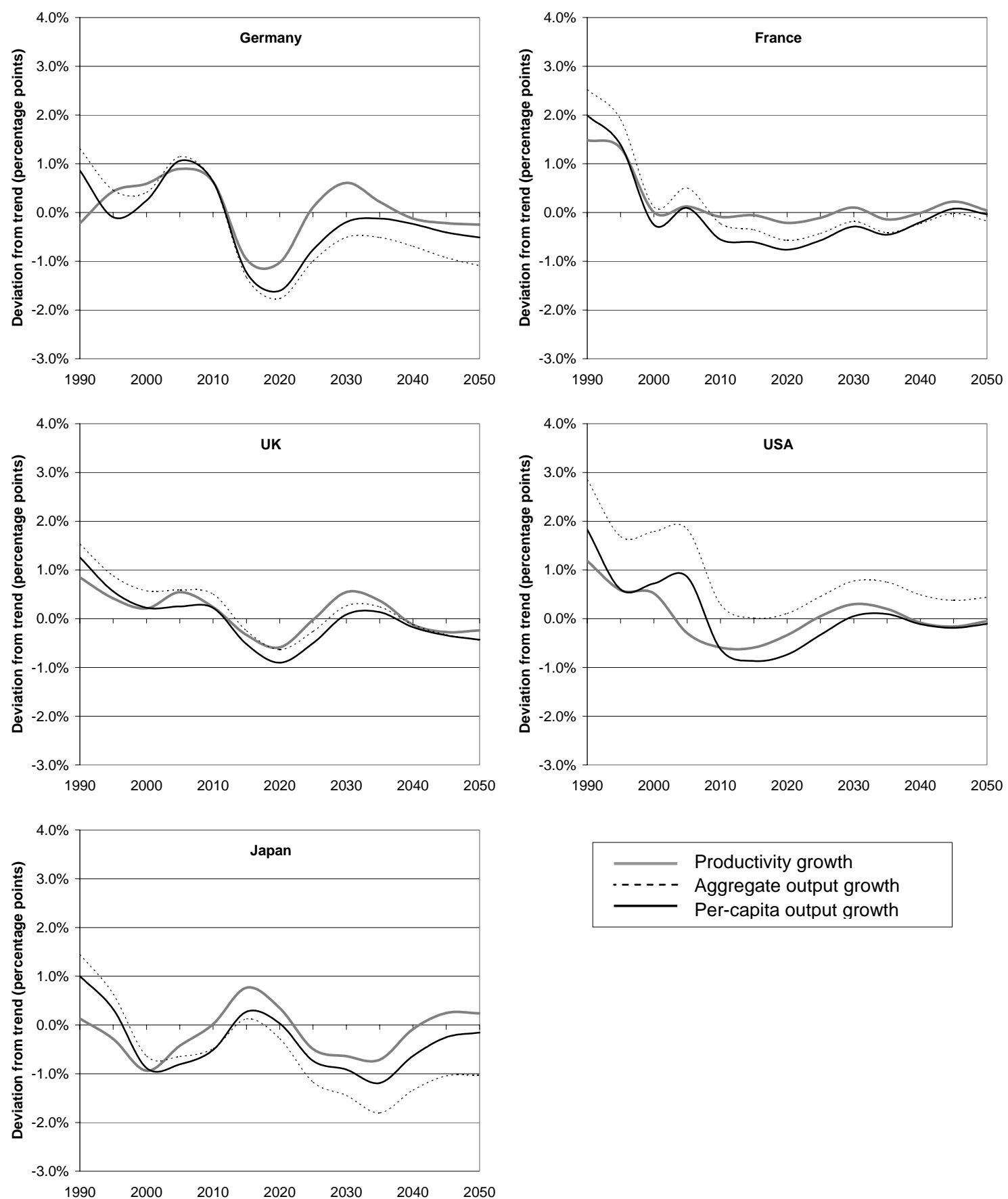

- Productivity growth

Sources: UN Population Division (2006; 2007), ILO (2007), author's estimates.

predictions for past and current developments, i.e., in the 1990-2005 sub-period, the estimates are able to explain, up to a point, the strong growth in productivity and aggregate output that the US has seen in the 1990s and also the underperformance that Japan 
was faced with in the same period. In the UK, above-trend growth in the 1990s and a current return to more moderate growth rates could also be derived from the estimates. The model works less good for France and Germany, where it predicts above-trend growth for the periods from 1990-95 and from 1995 onward to the present, respectively. In particular, the German growth performance has been relatively weak during the entire period from 1995 to $2005 .^{27}$

As to projected developments from 2005 onward, any of the growth rates I am looking at in Figure 2 is likely to exhibit much stronger fluctuations in Germany and Japan than it will in France, the UK and the US. Given past fertility trends and their consequences for the projected age composition of the labour force, this is probably not too surprising. However, the effects are very strong. The core result directly derived from the econometric estimates presented in Section 4.1 is that Germany as well as Japan may be faced with continued swings, both up and down, in productivity growth that could reach, or even exceed, 1 percentage point per year. Developments differ between these two countries because Japan had an early, and rather strong, post-war baby boom and a two-stage decline in birth rates afterwards, ${ }^{28}$ while the German baby boom was late and rather weak, followed by a very fast reduction in birth rates. In both cases, the resulting shifts in the demographic structure of the working-age population are becoming smaller over time, but last until around 2040. France, the UK and also the US will have a labour force with a relatively stable age structure, once the cohorts of their baby boomers have retired. The US, with a much stronger and more long-lasting baby boom than elsewhere, will have to deal with substantial changes in the age structure of their labour force over the next ten to fifteen years; thereafter, the effect will fade out. In the UK the baby boom was again smaller and took place later, giving rise to limited swings until around 2030. In France, where after an early and rather strong baby room birth rates never fell very low, there will be virtually no deviations from trend productivity growth caused by demographic shifts from 2005 onwards.

Taking into account the "participation” and "dependency” effects discussed in Section 2.1, the simulated changes in productivity growth translate into trend deviations in

27 A possible interpretation is that, due to a number of structural problems, Germany has effectively been forgoing the opportunity of some demographically induced extra-growth when the German baby boomers entered their 40s. By contrast, the US may have been able to exploit a similar opportunity during the 1990s, among other things because of their flexible labour markets. Of course, this reasoning does by no means imply that the same rigidities could also isolate a country against the downward risks for growth performance resulting from demographic changes projected for the future.

${ }^{28}$ In a sense, Japan has gone through the "first stage" of demographic transition, with a reduction in birth rates to a "replacement level" only in the short period between 1945 and 1955, while the same had happened around the beginning of the $20^{\text {th }}$ century in most other developed countries. As elsewhere, the Japanese birth rate started falling again in the mid-1970s - slower, but eventually to a lower level, than in Germany and, a fortiori, in the most other developed countries. 
the rates of aggregate growth and per-capita growth. In the US, the predicted demographic impact on aggregate growth is positive almost throughout, as the labour force in this country is projected to increase almost throughout, setting off all adverse effects for productivity. However, per-capita growth is negatively affected, due to an increase in dependency. In Germany and Japan, future reductions in aggregate growth are more pronounced than those in per-capita growth because, in these two countries, even total population is expected to decline, although at a smaller rate than their labour force. In any of these cases, the effects on output per capita are of course more important than those for aggregate output (see, again, Section 2.1). Also, it is interesting to note that the simulated impact of demographics on economic performance is not necessarily only a concern for the very long term. In Germany, assuming a common trend growth rate of productivity of about 1.5 per cent p.a. on real terms (which is about the average rate of annual real productivity growth in industrialized countries since 1990; see OECD 2007), demographic ageing could take away virtually all real growth of per-capita output in the period between 2010 and 2020. By contrast, the medium-term outlook for Japan appears to be a lot more friendly.

Because of the nature of macro-level evidence brought forth here, the foregoing analysis is certainly rough in many respects and one needs to interpret the findings with some care. Also, the analysis provides little detail that could be helpful in identifying the mechanisms at work behind the results, even though there are good reasons to investigate age-related productivity differentials using macroeconomic data (see Section 2.3). The results essentially support this view as they highlight a strong role of labour-force demographics for TFP and its growth. However, one can only speculate as to why this is so, while the estimates by themselves say nothing on how to answer this question. There are a number of plausible stories which could help explaining the observed pattern and, hence, might deserve further examination. Essentially, though, they would have to be investigated in a different framework and, more importantly, at another level. For example, the aggregate-level findings in this study could reflect effects of the age composition of work teams which originate at the firm level. The specific education-experience mix, or simply the way in which members of different age groups interact with each other in such teams, could easily matter for their total productivity. There could be other factors, such as entrepreneurship, creativity or simply pragmatism, which give prime-aged individuals a particular weight in determining TFP and TFP growth through the creation of new inventions or their successful exploitation. Starting from intriguing measurement problems, it would certainly not be easy to conceptualize and really investigate these issues. Still, the results derived in this paper may effectively define a research agenda that ought to be tackled when further exploring the economic implications of demographic ageing. 


\section{References}

Ahituv, A. (2001), "Be Fruitful or Multiply: On the Interplay between Fertility and Economic Development”, Journal of Population Economics 14, 51-71.

Barro, R.J. and J.-W. Lee (2001), "International Data on Educational Attainments: Updates and Implications”, Oxford Economic Papers 53, 541-563 (data download via http://www.cid.harvard.edu/ciddata/).

Barro, R.J. and X. Sala-i-Martin (1995), Economic Growth, New York: Mc Graw-Hill.

Bloom, D.E., D. Canning, G. Fink and J.E. Finlay (2007), “Does Age Structure Forecast Economic Growth?”, NBER Working Paper No. 13221.

Börsch-Supan, A. (2003), "Labor Market Effects of Population Aging”, Review of Labour Economics and Industrial Relations 17, 5-44.

Brandner, J.A. and S. Dowrick (1994), "The Role of Fertility and Population in Economic Growth: Empirical Results from Aggregate Cross-National Data”, Journal of Population Economics 7, 1-25.

Easterly, W. and R. Levine (2000), "It's Not Factor Accumulation: Stylized Facts and Growth Models”, Central Bank of Chile Working Papers No. 164.

European Commission (2005), “The Lisbon Strategy and the EU's Structural Productivity Problem”, European Economy, Economic Papers No. 221, Brussels: European Commission.

Fenge, R., S. Uebelmesser and M. Werding (2006), “On the Optimal Timing of Implicit Social Security Taxes Over the Life Cycle”, Finanzarchiv 62, 68-107.

Feyrer, J. (2007), “Demographics and Productivity”, Review of Economics and Statistics 89, 2007, 100-109 ( $c f$. also the longer 2002 version: mimeo, Dartmouth College).

Gollin, D. (2002), “Getting Income Shares Right”, Journal of Political Economy 110, 458-474.

Hall, R. and C.I. Jones (1999), "Why Do Some Countries Produce So Much More Output per Worker than Others?”, Quarterly Journal of Economics 114, 83-116.

Harrod, R.F. (1942), Toward a Dynamic Economics: Some Recent Developments of Economic Theory and their Application to Policy, London: Macmillan.

Heston, A., R. Summers and B. Aten (2006), Penn World Table (PWT) Version 6.2, Center for International Comparisons of Production, Income and Prices at the University of Pennsylvania (data download via http://pwt.econ.upenn.edu/).

Hicks, J. (1932), The Theory of Wages, London: Macmillan.

ILO (2007), ILO Database on Labour Statistics (LABORSTA) Version 08/2007, International Labour Office, Bureau of Statistics (data download via http://laborsta.ilo.org). 
Kotlikoff, L. and D.A. Wise (1989), “Employee Retirement and a Firm’s Pension Plan”, in: D.A. Wise (ed.), Topics in the Economics of Aging, Chicago: Chicago University Press, pp. 16-60.

Lindh, T. and B. Malmberg (1999), “Age Structure Effects and Growth in the OECD 1950-1990”, Journal of Population Economics 12, 431-449.

Lucas, R.E. (1988), “On the Mechanics of Economic Development”, Journal of Monetary Economics 22, 3-42.

Martins J.O., F. Gonand, P. Antolin, C. de la Mainonneuve and K.Y. Yoo (2005), “The Impact of Aging on Demand, Factor Markets and Growth”, OECD Economics Department Working Papers No. 420.

Mincer, J. (1974), Schooling, Experience and Earnings, New York: Columbia University Press.

OECD (2007), OECD Main Economic Indicators Version 07/2007, Organisation for Economic Co-operation and Development (data download via http://oecd.org).

Psacharopoulos, G. (1994), "Returns to Investment in Education: A Global Update”, World Development 22, 1325-1343.

Ramsey, F. (1928), “A Mathematical Theory of Saving”, Economic Journal 38, 543559.

Solow, R.M. (1956), “A Contribution to the Theory of Economic Growth”, Quarterly Journal of Economics 70, 65-94.

Solow, R.M. (1957), “Technical Change and the Aggregate Production Function”, Review of Economics and Statistics 39, 312-320.

Swan, T.W. (1956), "Economic Growth and Capital Accumulation”, Economic Record 32, 334-361.

UN Population Division (2006), Population Database, United Nations, Dept. of Economic and Social Affairs, Population Division (data download via http://www.un. org/esa/population/).

UN Population Division (2007), World Population Prospects: The 2006 Revision, United Nations, Dept. of Economic and Social Affairs, Population Division (data download via http://www.un.org/esa/population/).

Uzawa, H. (1961), "Neutral Inventions and the Stability of Growth Equilibrium”, Review of Economic Studies 28, 117-124.

Uzawa, H. (1965), “Optimum Technical Change in an Aggregative Model of Economic Growth”, International Economic Review 6, 18-31.

Werding (2007), “Ageing, Productivity and Economic Growth: A Macro-level Analysis”, Hitotsubashi University, Tokyo, PIE-CIS Discussion Paper Series No. 338. 


\section{Appendix}

A.1 List of countries included in the sample

\begin{tabular}{|c|c|c|c|}
\hline OECD countries (27): & \multicolumn{3}{|c|}{ Non-OECD countries (79): } \\
\hline Australia & Afghanistan & Guatemala & Papua New Guinea \\
\hline Austria & Algeria & Guinea-Bissau & Paraguay \\
\hline Belgium & Argentina & Haiti & Peru \\
\hline Canada & Bahrain & Honduras & Philippines \\
\hline Denmark & Bangladesh & Hong Kong & Rwanda \\
\hline Finland & Barbados & India & Senegal \\
\hline France & Benin & Indonesia & Sierra Leone \\
\hline Germany & Bolivia & Iran & Singapore \\
\hline Greece & Botswana & Iraq & South Africa \\
\hline Hungary & Brazil & Israel & Sri Lanka \\
\hline Iceland & Burundi & Jamaica & Sudan \\
\hline Ireland & Chile & Jordan & Swaziland \\
\hline Italy & China & Kenya & Syria \\
\hline Japan & Cameroon & Kuwait & Tanzania \\
\hline Korea, Rep. of & Central African Rep. & Liberia & Thailand \\
\hline Mexico & Colombia & Lesotho & Togo \\
\hline Netherlands & Congo, Dem. Rep. & Malawi & Trinidad \& Tobago \\
\hline New Zealand & Congo, Rep. of & Malaysia & Tunisia \\
\hline Norway & Costa Rica & Mali & Uganda \\
\hline Poland & Cyprus & Mauritania & United Arab Emirates \\
\hline Portugal & Dominican Rep. & Mauritius & Uruguay \\
\hline Spain & Ecuador & Mozambique & Venezuela \\
\hline Sweden & Egypt & Nicaragua & Yemen \\
\hline Switzerland & El Salvador & Niger & Zambia \\
\hline Turkey & Fiji & Nepal & Zimbabwe \\
\hline United Kingdom & Gambia & Pakistan & \\
\hline United States & Ghana & Panama & \\
\hline
\end{tabular}

With data spanning the period from 1960 to 2000 at 5-year intervals, the maximum number of observations for each country is 9 . The average number of observations which enter the level-estimates reported in Section 4.1 is 8.1 for the "all countries" sample, 8.6 for the OECD sample. In the growth-estimates that follow, differencing implies a reduction by one observation per country (while countries with just one observation drop out). Here the average number of observations is 7.4 and 7.6, respectively. For several reasons, sample size is further reduced in terms of countries and/or observations in the estimates reported in Section 4.2 and in the appendix. 


\section{A.2 Descriptive Statistics}

\begin{tabular}{|l|c|c|c|c|}
\hline Variables & Mean & Std. dev. & Min. & Max. \\
\hline Growth accounting: & & & & \\
$q$ (real GDP per worker, US-\$) & 17,214 & 16,786 & 487 & 196,173 \\
$\kappa$ (capital coefficient) & 1.3623 & 0.8195 & 0.0892 & 6.2989 \\
ln $h$ (log measure of hum. cap.) & 0.6056 & 0.3351 & 0.0141 & 1.3962 \\
$\ln$ A (log TFP measure) & 8.5801 & 0.7995 & 5.0615 & 12.4691 \\
\hline Labour force by age groups: & & & & \\
L10-19 (share in total $L$ ) & 0.1535 & 0.0699 & 0.0031 & 0.3063 \\
L20-29 (share in total $L$ ) & 0.2806 & 0.0370 & 0.1780 & 0.4380 \\
L30-39 (share in total $L$ ) & 0.2247 & 0.0343 & 0.1213 & 0.4046 \\
L40-49 (share in total $L$ ) & 0.1674 & 0.0350 & 0.1041 & 0.3010 \\
L50-59 (share in total $L$ ) & 0.1105 & 0.0296 & 0.0596 & 0.2243 \\
L60plus (share in total $L$ ) & 0.0633 & 0.0209 & 0.0039 & 0.1583 \\
\hline Human capital by age groups: & & & & \\
h10-19 (relative to $\ln h$ ) & 1.2691 & 0.3692 & 0.1972 & 3.4578 \\
h20-29 (relative to $\ln h$ ) & 1.2311 & 0.1870 & 0.6966 & 2.2302 \\
h30-39 (relative to $\ln h$ ) & 0.9895 & 0.1969 & 0.3649 & 2.1448 \\
h40-49 (relative to $\ln h$ ) & 0.8237 & 0.2256 & 0.0000 & 1.7753 \\
h50-59 (relative to $\ln h$ ) & 0.7515 & 0.2646 & 0.0000 & 1.8850 \\
h60plus (relative to $\ln h$ ) & 0.7416 & 0.3923 & 0.0000 & 2.7021 \\
\hline
\end{tabular}

\begin{tabular}{|l|cccccc|}
\hline \multicolumn{7}{|c|}{ Correlation Matrices } \\
\hline & $\ln A$ & $\ln q$ & $\ln \kappa$ & $\ln h$ & & \\
$\ln A$ & 1.0000 & & & & & \\
$\ln q$ & 0.8376 & 1.0000 & & & & \\
$\ln \kappa$ & 0.0336 & 0.5339 & 1.0000 & & & \\
$\ln h$ & 0.3804 & 0.7727 & 0.6296 & 1.0000 & & \\
\hline & $\ln A$ & $L 1019$ & $L 2029$ & $L 3039$ & $L 4049$ & \\
$\ln A$ & 1.0000 & & & & & \\
$L 1019$ & -0.5381 & 1.0000 & & & & \\
$L 2029$ & 0.0644 & 0.0246 & 1.0000 & & & \\
$L 3039$ & 0.4073 & -0.7427 & 0.1118 & 1.0000 & & \\
$L 4049$ & 0.4193 & -0.8091 & -0.4695 & 0.5744 & 1.0000 & \\
$L 5059$ & 0.3228 & -0.6403 & -0.5953 & 0.1408 & 0.7332 & 1.0000 \\
$L 60$ plus & -0.1405 & 0.0950 & -0.3970 & -0.5220 & -0.1243 & 0.3195 \\
\hline & $\ln h$ & $h 1019$ & $h 2029$ & $h 3039$ & $h 4049$ & $h 5059$ \\
$\ln h$ & 1.0000 & & & & & \\
$h 1019$ & -0.5920 & 1.0000 & & & & \\
$h 2029$ & -0.3288 & 0.5438 & 1.0000 & & & \\
$h 3030$ & 0.3359 & -0.5816 & 0.1993 & 1.0000 & & \\
$h 4049$ & 0.5076 & -0.6442 & -0.6200 & 0.4562 & 1.0000 & \\
5059 & 0.4363 & -0.4899 & -0.8128 & -0.1815 & 0.6679 & 1.0000 \\
$h 60 \mathrm{plus}$ & 0.2625 & -0.2857 & -0.6246 & -0.3363 & 0.2016 & 0.7360 \\
\hline
\end{tabular}


A.3 The age composition of the labour force and TFP: estimates for "non-oil" samples

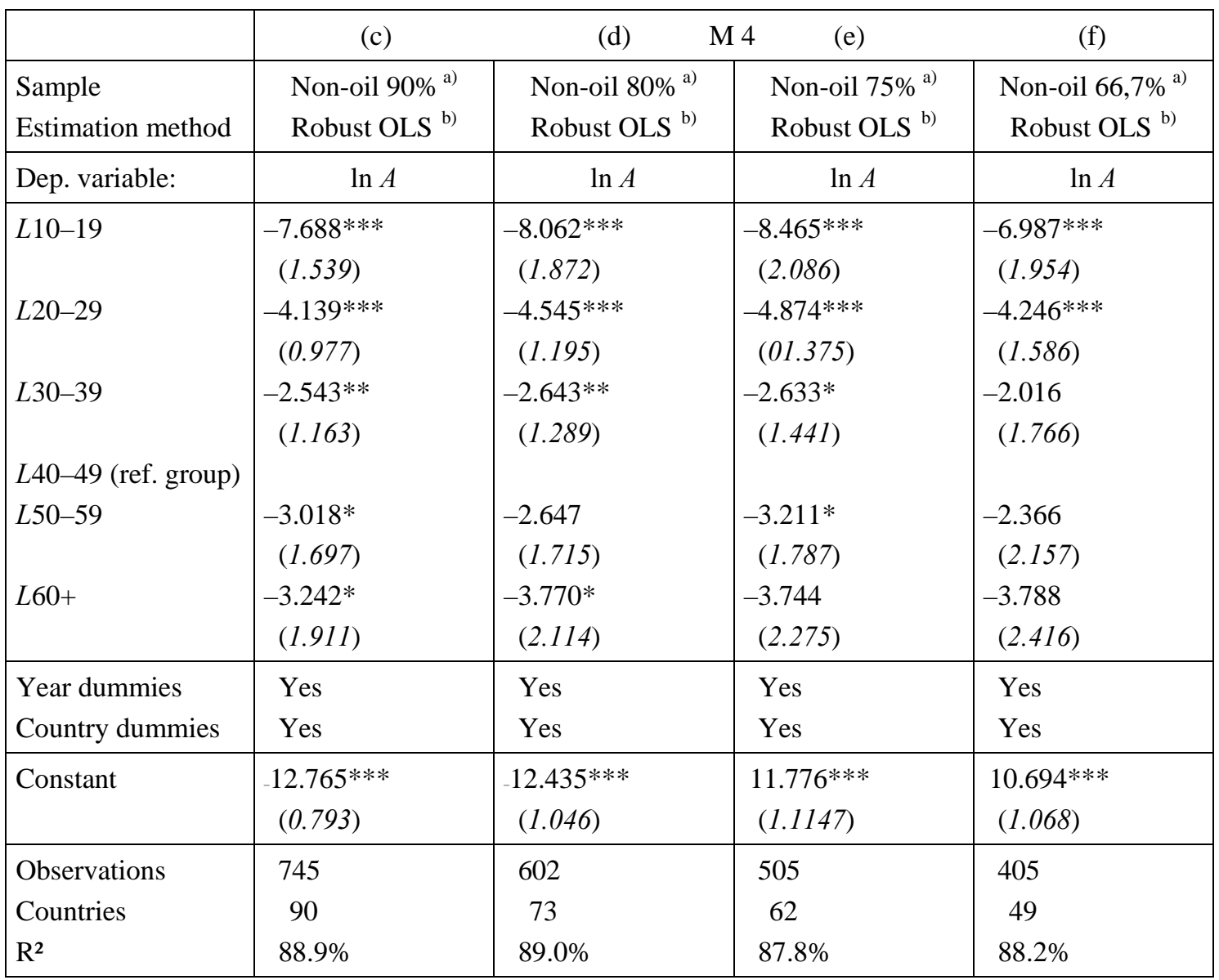

a) "Non-oil $X \%$ " means that countries are excluded if, in the 1960-2000 period, the share of fuel exports in total merchandise exports was more than once at or above the $X^{\text {th }}$ percentile of the annual global distribution of these shares. Countries for which data on foreign trade are lacking are also omitted.

b) Residuals clustered by countries to avoid distortions of standard errors through serial correlation. ***, ** and * denote significance at a 1-percent, 5-percent or 10-percent level, respectively. (Standard errors are in parentheses.) 
A.4 The age composition of the labour force, TFP and TFP growth: estimates for the samples with detailed human-capital data

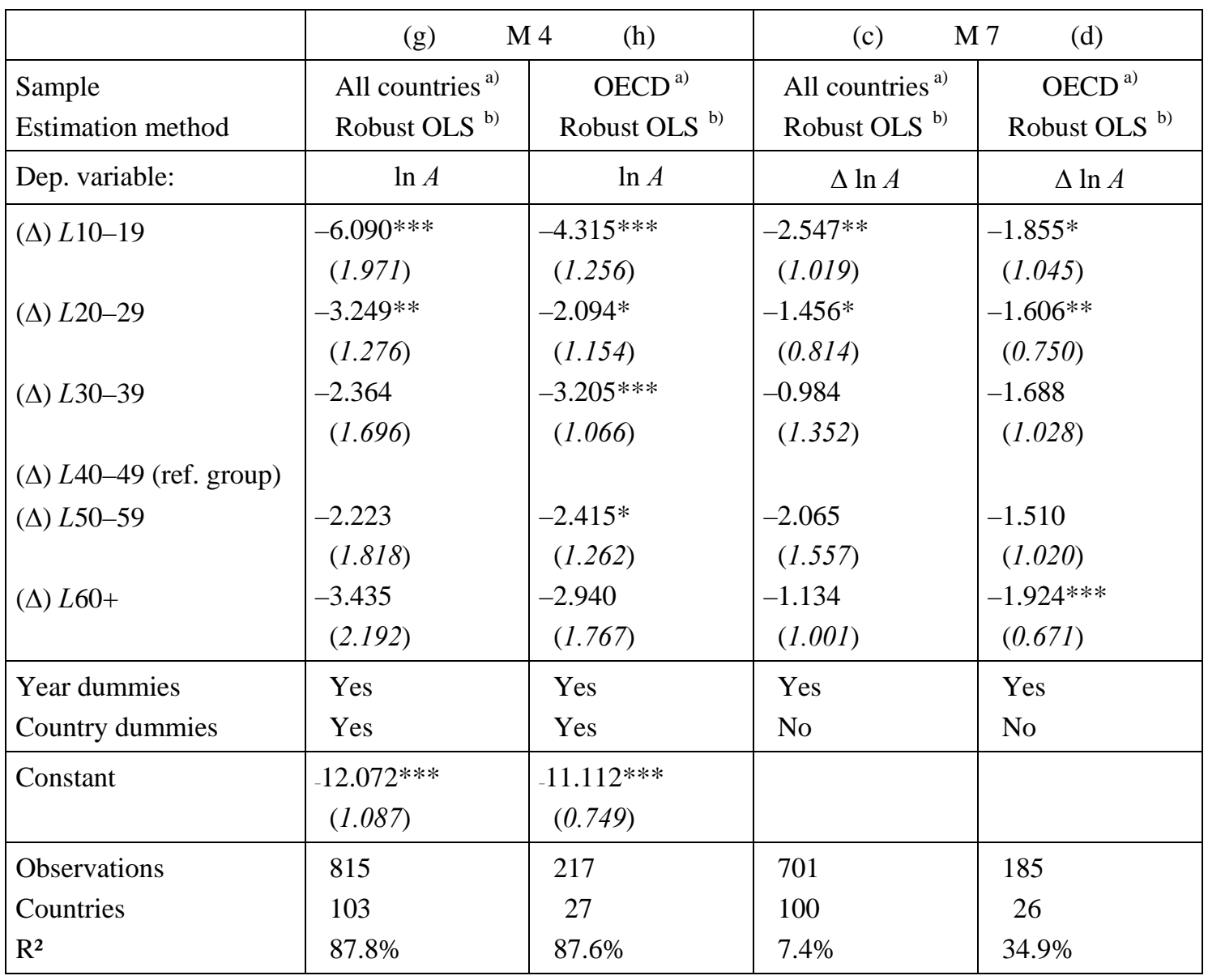

a) Samples restricted to observations for which data on the age composition of human capital as used in models M 11 and M 12 are available.

b) Residuals clustered by countries to avoid distortions of standard errors through serial correlation. $* * *$, ** and * denote significance at a 1-percent, 5-percent or 10-percent level, respectively. (Standard errors are in parentheses.) 
A.5 The age distribution of human capital, TFP and TFP growth: estimates without imputed figures for age-specific human capital

\begin{tabular}{|c|c|c|c|c|c|c|c|}
\hline & (a) & (b) & (c) & M 13 (d) & (e) & (f) & (g) \\
\hline Sample & \multicolumn{7}{|c|}{ All countries ${ }^{\text {a) }}$} \\
\hline Estim. method & \multirow{2}{*}{$\frac{\text { Pool. OLS }}{\ln A}$} & \multicolumn{4}{|c|}{ Robust OLS ${ }^{\text {b) }}$} & \multicolumn{2}{|c|}{ Pooled OLS } \\
\hline Dep. variable: & & $\ln A$ & $\ln A$ & $\ln A$ & $\ln A$ & $\ln A$ & $\ln A$ \\
\hline L10-19 & $\begin{array}{c}-7.867 * * \\
(3.063)\end{array}$ & $\begin{array}{r}-4.460 * \\
(2.411)\end{array}$ & $\begin{array}{r}-4.767^{*} \\
(2.671)\end{array}$ & $\begin{array}{r}-4.994^{*} \\
(2.722)\end{array}$ & $\begin{array}{r}-6.373 \\
(6.654)\end{array}$ & $\begin{array}{c}-8.482 * * * \\
(2.849)\end{array}$ & $\begin{array}{c}-8.452 * * * \\
(2.842)\end{array}$ \\
\hline$L 20-29$ & $\begin{array}{r}-2.350 \\
(2.861)\end{array}$ & $\begin{array}{c}-2.558 * * \\
(1.236)\end{array}$ & $\begin{array}{c}-2.892 * * \\
(1.300)\end{array}$ & $\begin{array}{c}-3.903 * * * \\
(1.334)\end{array}$ & $\begin{array}{r}-2.905 \\
(1.822)\end{array}$ & $\begin{array}{r}-3.589 \\
(2.719)\end{array}$ & $\begin{array}{r}-3.593 \\
(2.709)\end{array}$ \\
\hline L30-39 & $\begin{array}{r}-0.831 \\
(5.190)\end{array}$ & $\begin{array}{r}-1.606 \\
(1.568)\end{array}$ & $\begin{array}{r}-1.641 \\
(1.694)\end{array}$ & $\begin{array}{r}-1.893 \\
(1.219)\end{array}$ & $\begin{array}{r}-1.189 \\
(1.687)\end{array}$ & $\begin{array}{r}-1.684 \\
(4.990)\end{array}$ & $\begin{array}{r}-1.608 \\
(4.994)\end{array}$ \\
\hline L40-49 (ref. gr.) & & & & & & & \\
\hline L50-59 & $\begin{array}{r}-0.333 \\
(5.443)\end{array}$ & $\begin{array}{r}-1.201 \\
(1.861)\end{array}$ & $\begin{array}{r}-1.162 \\
(1.908)\end{array}$ & $\begin{array}{r}-1.821 \\
(2.326)\end{array}$ & $\begin{array}{l}1.220 \\
(1.990)\end{array}$ & $\begin{array}{r}-3.253 \\
(4.900)\end{array}$ & $\begin{array}{r}-2.993 \\
(4.978)\end{array}$ \\
\hline$L 60+$ & $\begin{array}{c}-8.428 * * \\
(4.075)\end{array}$ & $\begin{array}{r}-3.459 * \\
(1.968)\end{array}$ & $\begin{array}{r}-3.520 \\
(2.184)\end{array}$ & $\begin{array}{r}-1.329 \\
(2.833)\end{array}$ & $\begin{array}{r}-8.781 \\
(8.682)\end{array}$ & $\begin{array}{c}-9.605^{* *} \\
(3.951)\end{array}$ & $\begin{array}{c}-9.598 * * \\
(3.948)\end{array}$ \\
\hline h10-19 & $\begin{array}{r}-0.222 \\
(0.772)\end{array}$ & $\begin{array}{l}0.167 \\
(0.113)\end{array}$ & & & & & \\
\hline$h 20-29$ & $\begin{array}{l}0.709 \\
(1.815)\end{array}$ & & $\begin{array}{l}0.156 \\
(0.153)\end{array}$ & & & & \\
\hline$h 30-39$ & $\begin{array}{r}-0.671 \\
(2.385)\end{array}$ & & & $\begin{array}{r}-0.132 \\
(0.167)\end{array}$ & & & \\
\hline$h 40-49$ & $\begin{array}{r}-1.389 \\
(2.040)\end{array}$ & & & & $\begin{array}{r}-0.153 \\
(0.171)\end{array}$ & & \\
\hline h50-59 & $\begin{array}{l}1.688 \\
(1.335)\end{array}$ & & & & & $\begin{array}{r}-0.020 \\
(0.258)\end{array}$ & \\
\hline$h 60+$ & $\begin{array}{r}-0.715 \\
(0.464)\end{array}$ & & & & & & $\begin{array}{r}-0.055 \\
(0.184)\end{array}$ \\
\hline Year dummies & No & Yes & Yes & Yes & Yes & No & No \\
\hline Ctry. dummies & No & Yes & Yes & Yes & Yes & No & No \\
\hline Constant & $\begin{array}{c}11.436 * * * \\
(2.918)\end{array}$ & $\begin{array}{c}11.149 * * * \\
(1.054)\end{array}$ & $\begin{array}{c}11.292 * * * \\
(1.401)\end{array}$ & $\begin{array}{c}11.993 * * * \\
(1.424)\end{array}$ & $\begin{array}{c}11.387 * * * \\
(2.253)\end{array}$ & $\begin{array}{c}11.893 * * * \\
(2.737)\end{array}$ & $\begin{array}{c}11.859 * * * \\
(2.727)\end{array}$ \\
\hline Observations & 86 & 661 & 660 & 469 & 276 & 91 & 91 \\
\hline Countries & 86 & 100 & 100 & 99 & 96 & 91 & 91 \\
\hline $\mathrm{R}^{2}$ & $63.8 \%$ & $88.9 \%$ & $88.8 \%$ & $92.8 \%$ & $96.3 \%$ & $60.1 \%$ & $60.1 \%$ \\
\hline
\end{tabular}

a) Samples restricted to observations for which data on the age composition of human capital are available that have not been imputed based on Step 2 of the procedures explained in footnote 21 .

b) Residuals clustered by countries to avoid distortions of standard errors through serial correlation. $* * *, * *$ and * denote significance at a 1-percent, 5-percent or 10-percent level, respectively. (Standard errors are in parentheses.) 
A.5 (cont'd.) The age distribution of human capital, TFP and TFP growth: estimates without imputed figures for age-specific human capital

\begin{tabular}{|c|c|c|c|c|c|c|}
\hline & \multicolumn{4}{|c|}{ (c) $\quad \mathrm{M} 14 \quad$ (d) } & (e) & (f) \\
\hline $\begin{array}{l}\text { Sample } \\
\text { Estimation method }\end{array}$ & \multicolumn{6}{|c|}{$\begin{array}{l}\text { All countries }{ }^{\text {a) }} \\
\text { Robust OLS }\end{array}$} \\
\hline Dep. variable: & $\Delta \ln A$ & $\Delta \ln A$ & $\Delta \ln A$ & $\Delta \ln A$ & $\Delta \ln A$ & $\Delta \ln A$ \\
\hline$\Delta L 10-19$ & $\begin{array}{l}-3.297 \\
(2.037)\end{array}$ & $\begin{array}{r}-10.405 \\
(6.494)\end{array}$ & $\begin{array}{r}-2.972 * \\
(1.764)\end{array}$ & $\begin{array}{l}-2.882 \\
(1.871)\end{array}$ & $\begin{array}{r}-3.928^{*} \\
(2.041)\end{array}$ & $\begin{array}{r}-10.784 \\
(6.835)\end{array}$ \\
\hline$\Delta L 20-29$ & $\begin{array}{l}-2.643 \\
(1.834)\end{array}$ & $\begin{array}{c}-4.373^{* *} \\
(2.154)\end{array}$ & $\begin{array}{c}-2.382 * * \\
(1.037)\end{array}$ & $\begin{array}{c}-2.410^{* *} \\
(0.954)\end{array}$ & $\begin{array}{r}-2.961^{*} \\
(1.693)\end{array}$ & $\begin{array}{c}-4.688 * * \\
(1.988)\end{array}$ \\
\hline$\Delta L 30-39$ & $\begin{array}{l}0.395 \\
(1.130)\end{array}$ & $\begin{array}{l}0.595 \\
(1.640)\end{array}$ & $\begin{array}{l}-0.597 \\
(1.028)\end{array}$ & $\begin{array}{l}-0.414 \\
(1.020)\end{array}$ & $\begin{array}{l}-0.098 \\
(1.046)\end{array}$ & $\begin{array}{l}-0.197 \\
(1.459)\end{array}$ \\
\hline$\Delta L 40-49$ (ref. gr.) & & & & & & \\
\hline$\Delta L 50-59$ & $\begin{array}{l}-1.701 \\
(2.295)\end{array}$ & $\begin{array}{l}0.468 \\
(2.169)\end{array}$ & $\begin{array}{l}-1.142 \\
(2.053)\end{array}$ & $\begin{array}{l}-1.387 \\
(2.077)\end{array}$ & $\begin{array}{l}-1.804 \\
(2.242)\end{array}$ & $\begin{array}{l}-0.093 \\
(1.931)\end{array}$ \\
\hline$\Delta L 60+$ & $\begin{array}{l}-0.197 \\
(1.921)\end{array}$ & $\begin{array}{r}-10.425 \\
(9.200)\end{array}$ & $\begin{array}{l}-1.203 \\
(1.329)\end{array}$ & $\begin{array}{l}-0.590 \\
(1.360)\end{array}$ & $\begin{array}{l}-1.030 \\
(2.039)\end{array}$ & $\begin{array}{r}-11.598 \\
(7.990)\end{array}$ \\
\hline$\Delta h 10-19$ & $\begin{array}{l}-0.025 \\
(0.094)\end{array}$ & $\begin{array}{l}0.060 \\
(0.164)\end{array}$ & $\begin{array}{l}0.051 \\
(0.072)\end{array}$ & & & \\
\hline$\Delta h 20-29$ & $\begin{array}{l}0.0389 * \\
(0.198)\end{array}$ & $\begin{array}{l}0.591 \\
(0.375)\end{array}$ & & $\begin{array}{l}0.338^{* * * *} \\
(0.108)\end{array}$ & & \\
\hline$\Delta h 30-39$ & $\begin{array}{l}-0.133 \\
(0.186)\end{array}$ & $\begin{array}{l}-0.188 \\
(0.341)\end{array}$ & & & $\begin{array}{l}0.053 \\
(0.134)\end{array}$ & \\
\hline & & $\begin{array}{l}0.036 \\
(0.209)\end{array}$ & & & & $\begin{array}{l}-0.124 \\
(0.119)\end{array}$ \\
\hline$\Delta h 50-59$ & & & & & & \\
\hline$\Delta h 60+$ & & & & & & \\
\hline Year dummies & Yes & Yes & Yes & Yes & Yes & Yes \\
\hline Country dummies & No & No & No & No & No & No \\
\hline Observations & 360 & 172 & 556 & 555 & 368 & 180 \\
\hline Countries & 96 & 87 & 100 & 99 & 98 & 92 \\
\hline $\mathrm{R}^{2}$ & $14.6 \%$ & $30.2 \%$ & $8.5 \%$ & $10.4 \%$ & $13.5 \%$ & $28.0 \%$ \\
\hline
\end{tabular}

a) Samples restricted to observations for which data on the age composition of human capital are available that have not been imputed based on Step 2 of the procedures explained in footnote 21 .

b) Residuals clustered by countries to avoid distortions of standard errors through serial correlation. ***, ** and * denote significance at a 1-percent, 5-percent or 10-percent level, respectively. (Standard errors are in parentheses.) 


\section{CESifo Working Paper Series}

for full list see www.cesifo-group.org/wp

(address: Poschingerstr. 5, 81679 Munich, Germany, office@cesifo.de)

2144 Kai A. Konrad, Mobile Tax Base as a Global Common, November 2007

2145 Ola Kvaløy and Trond E. Olsen, The Rise of Individual Performance Pay, November 2007

2146 Guglielmo Maria Caporale, Yannis Georgellis, Nicholas Tsitsianis and Ya Ping Yin, Income and Happiness across Europe: Do Reference Values Matter?, November 2007

2147 Dan Anderberg, Tax Credits, Income Support and Partnership Decisions, November 2007

2148 Andreas Irmen and Rainer Klump, Factor Substitution, Income Distribution, and Growth in a Generalized Neoclassical Model, November 2007

2149 Lorenz Blume, Jens Müller and Stefan Voigt, The Economic Effects of Direct Democracy - A First Global Assessment, November 2007

2150 Axel Dreher, Pierre-Guillaume Méon and Friedrich Schneider, The Devil is in the Shadow - Do Institutions Affect Income and Productivity or only Official Income and Official Productivity?, November 2007

2151 Valentina Bosetti, Carlo Carraro, Emanuele Massetti and Massimo Tavoni, International Energy R\&D Spillovers and the Economics of Greenhouse Gas Atmospheric Stabilization, November 2007

2152 Balázs Égert and Dubravko Mihaljek, Determinants of House Prices in Central and Eastern Europe, November 2007

2153 Christa Hainz and Hendrik Hakenes, The Politician and his Banker, November 2007

2154 Josef Falkinger, Distribution and Use of Knowledge under the "Laws of the Web", December 2007

2155 Thorvaldur Gylfason and Eduard Hochreiter, Growing Apart? A Tale of Two Republics: Estonia and Georgia, December 2007

2156 Morris A. Davis and François Ortalo-Magné, Household Expenditures, Wages, Rents, December 2007

2157 Andreas Haufler and Christian Schulte, Merger Policy and Tax Competition, December 2007

2158 Marko Köthenbürger and Panu Poutvaara, Rent Taxation and its Intertemporal Welfare Effects in a Small Open Economy, December 2007 
2159 Betsey Stevenson, Title IX and the Evolution of High School Sports, December 2007

2160 Stergios Skaperdas and Samarth Vaidya, Persuasion as a Contest, December 2007

2161 Morten Bennedsen and Christian Schultz, Arm's Length Provision of Public Services, December 2007

2162 Bas Jacobs, Optimal Redistributive Tax and Education Policies in General Equilibrium, December 2007

2163 Christian Jaag, Christian Keuschnigg and Mirela Keuschnigg, Pension Reform, Retirement and Life-Cycle Unemployment, December 2007

2164 Dieter M. Urban, Terms of Trade, Catch-up, and Home Market Effect: The Example of Japan, December 2007

2165 Marcelo Resende and Rodrigo M. Zeidan, Lionel Robbins: A Methodological Reappraisal, December 2007

2166 Samuel Bentolila, Juan J. Dolado and Juan F. Jimeno, Does Immigration Affect the Phillips Curve? Some Evidence for Spain, December 2007

2167 Rainald Borck, Federalism, Fertility and Growth, December 2007

2168 Erkki Koskela and Jan König, Strategic Outsourcing, Profit Sharing and Equilibrium Unemployment, December 2007

2169 Egil Matsen and Øystein Thøgersen, Habit Formation, Strategic Extremism and Debt Policy, December 2007

2170 Torben M. Andersen and Allan Sørensen, Product Market Integration and Income Taxation: Distortions and Gains from Trade, December 2007

2171 J. Atsu Amegashie, American Idol: Should it be a Singing Contest or a Popularity Contest?, December 2007

2172 Patricia Apps and Ray Rees, Household Models: An Historical Perspective, December 2007

2173 Ben Greiner, Axel Ockenfels and Peter Werner, The Dynamic Interplay of Inequality and Trust - An Experimental Study, December 2007

2174 Michael Melvin and Magali Valero, The Dark Side of International Cross-Listing: Effects on Rival Firms at Home, December 2007

2175 Gebhard Flaig and Horst Rottmann, Labour Market Institutions and the Employment Intensity of Output Growth. An International Comparison, December 2007

2176 Alexander Chudik and M. Hashem Pesaran, Infinite Dimensional VARs and Factor Models, December 2007 
2177 Christoph Moser and Axel Dreher, Do Markets Care about Central Bank Governor Changes? Evidence from Emerging Markets, December 2007

2178 Alessandra Sgobbi and Carlo Carraro, A Stochastic Multiple Players Multi-Issues Bargaining Model for the Piave River Basin, December 2007

2179 Christa Hainz, Creditor Passivity: The Effects of Bank Competition and Institutions on the Strategic Use of Bankruptcy Filings, December 2007

2180 Emilia Del Bono, Andrea Weber and Rudolf Winter-Ebmer, Clash of Career and Family: Fertility Decisions after Job Displacement, January 2008

2181 Harald Badinger and Peter Egger, Intra- and Inter-Industry Productivity Spillovers in OECD Manufacturing: A Spatial Econometric Perspective, January 2008

2182 María del Carmen Boado-Penas, Salvador Valdés-Prieto and Carlos Vidal-Meliá, the Actuarial Balance Sheet for Pay-As-You-Go Finance: Solvency Indicators for Spain and Sweden, January 2008

2183 Assar Lindbeck, Economic-Social Interaction in China, January 2008

2184 Pierre Dubois, Bruno Jullien and Thierry Magnac, Formal and Informal Risk Sharing in LDCs: Theory and Empirical Evidence, January 2008

2185 Roel M. W. J. Beetsma, Ward E. Romp and Siert J. Vos, Intergenerational Risk Sharing, Pensions and Endogenous Labor Supply in General Equilibrium, January 2008

2186 Lans Bovenberg and Coen Teulings, Rhineland Exit?, January 2008

2187 Wolfgang Leininger and Axel Ockenfels, The Penalty-Duel and Institutional Design: Is there a Neeskens-Effect?, January 2008

2188 Sándor Csengődi and Dieter M. Urban, Foreign Takeovers and Wage Dispersion in Hungary, January 2008

2189 Joerg Baten and Andreas Böhm, Trends of Children's Height and Parental Unemployment: A Large-Scale Anthropometric Study on Eastern Germany, 1994 2006, January 2008

2190 Chris van Klaveren, Bernard van Praag and Henriette Maassen van den Brink, A Public Good Version of the Collective Household Model: An Empirical Approach with an Application to British Household Data, January 2008

2191 Harry Garretsen and Jolanda Peeters, FDI and the Relevance of Spatial Linkages: Do third Country Effects Matter for Dutch FDI?, January 2008

2192 Jan Bouckaert, Hans Degryse and Theon van Dijk, Price Discrimination Bans on Dominant Firms, January 2008 
2193 M. Hashem Pesaran, L. Vanessa Smith and Takashi Yamagata, Panel Unit Root Tests in the Presence of a Multifactor Error Structure, January 2008

2194 Tomer Blumkin, Bradley J. Ruffle and Yosef Ganun, Are Income and Consumption Taxes ever really Equivalent? Evidence from a Real-Effort Experiment with Real Goods, January 2008

2195 Mika Widgrén, The Impact of Council's Internal Decision-Making Rules on the Future EU, January 2008

2196 Antonis Adam, Margarita Katsimi and Thomas Moutos, Inequality and the Import Demand Function, January 2008

2197 Helmut Seitz, Democratic Participation and the Size of Regions: An Empirical Study Using Data on German Counties, January 2008

2198 Theresa Fahrenberger and Hans Gersbach, Minority Voting and Long-term Decisions, January 2008

2199 Chiara Dalle Nogare and Roberto Ricciuti, Term Limits: Do they really Affect Fiscal Policy Choices?, January 2008

2200 Andreas Bühn and Friedrich Schneider, MIMIC Models, Cointegration and Error Correction: An Application to the French Shadow Economy, January 2008

2201 Seppo Kari, Hanna Karikallio and Jukka Pirttilä, Anticipating Tax Change: Evidence from the Finnish Corporate Income Tax Reform of 2005, January 2008

2202 Walter Krämer and André Güttler, On Comparing the Accuracy of Default Predictions in the Rating Industry, January 2008

2203 Syed M. Ahsan and Panagiotis Tsigaris, The Efficiency Loss of Capital Income Taxation under Imperfect Loss Offset Provisions, January 2008

2204 P. Mohnen, F. C. Palm, S. Schim van der Loeff and A. Tiwari, Financial Constraints and other Obstacles: Are they a Threat to Innovation Activity?, January 2008

2205 Sascha O. Becker and Mathias Hoffmann, Equity Fund Ownership and the CrossRegional Diversification of Household Risk, January 2008

2206 Pedro R. D. Bom and Jenny E. Ligthart, How Productive is Public Capital? A MetaAnalysis, January 2008

2207 Martin Werding, Ageing and Productivity Growth: Are there Macro-level Cohort Effects of Human Capital?, January 2008 